\title{
تأثير التبييض باستخدام بيربورات الصوديوم على خواص الأداء الوظيفى لأقمشة المفروشات القطنية
}

\author{
اعلداد \\ م/ أسماء سامسـ عبدالعاطحس سويلم \\ مدرس الملابس والنسيج بقسم الإقتصاد المنزلي

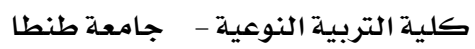

مجلة بحوث التربية النوعية ـ جامعة المنصورة

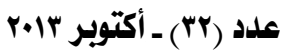




\section{تأثير التبيسض باستخدام بيربورات الصوديوم على خواص الأداء الوظيفى لأقمشة الفروشات القطنية}

إعداد

* دأسماء سامي عبد العاطي سورلم

\section{:صغا||}

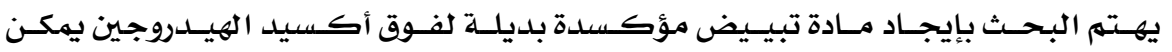

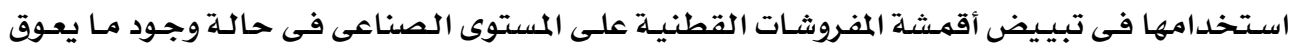

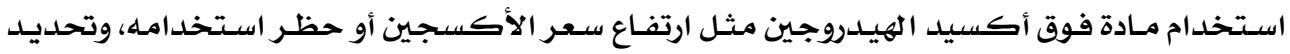

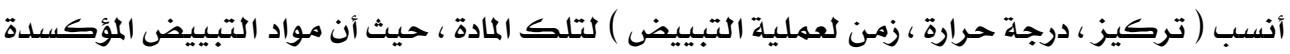

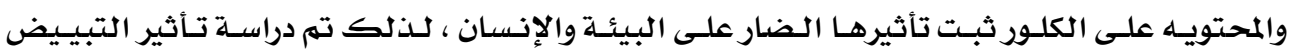

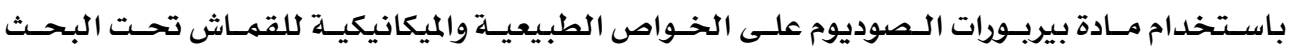

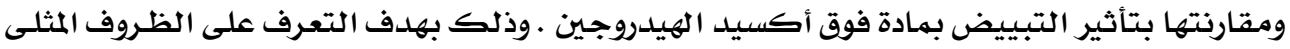

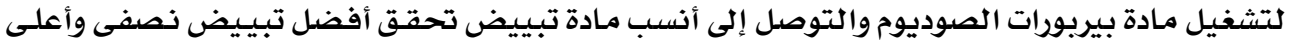

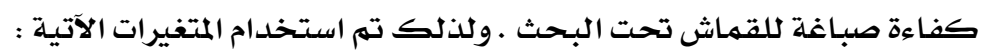

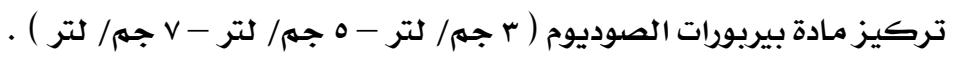

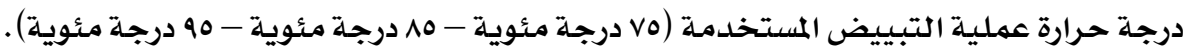

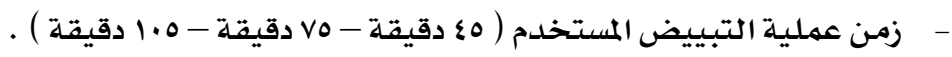

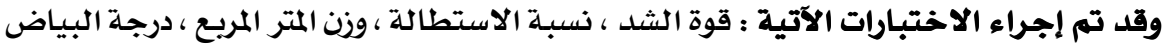

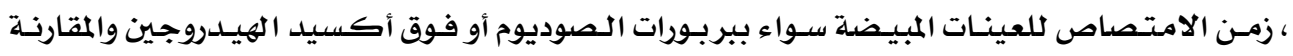

وبعد التوصل أنسب ظروف لتشغيل مادة بيربورات الصوديوم ، تم صباغة العينات المبيضة بكلا

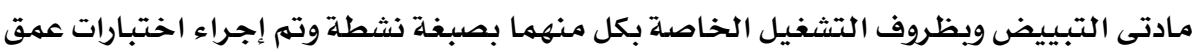

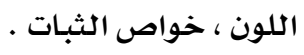

ثم تم تطبيق الأسلوب الإحصائى المناسب على نتائج هذه الاختبارات ، وكانت أهم النتائج التى توصل إليها البحث :

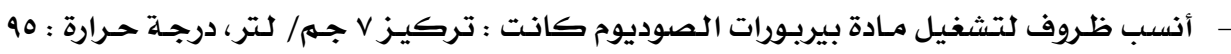

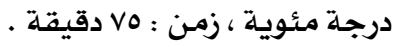

مدرس الملابس والنسيج بقسم الإقتصاد المنزلي- كلية التربية النوعية - جامعة طنطا 


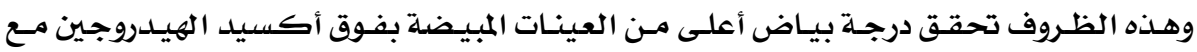
الحفاظ على الخواص الطبيعية والميكانيكية للقماث المستخدم .

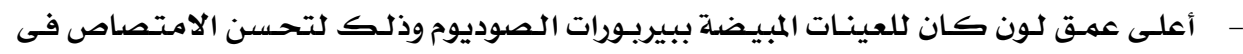

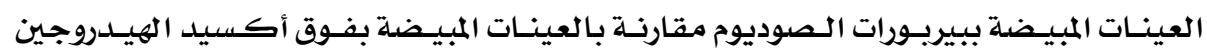
بلدرجة ملـحوظة . حققت مـادة بيربورات الصوديوم أعلى قيهم فى خواص ثبات اللون مـا عدا الثبات كلاحتكاك فلم يعط فروق معنويـة بيـن مـادتى التبييض ، وذلك بالمقارنـة بـين مـادتى بيربـورات الصوديوم وفوق

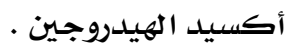

إن الغـرض مـن عمليـة تبـيـيض الأليـاف القطنيـة هـو إزالـة اللـون الطبيعـى الـذى لا يهكـن التخلص منـه أثناء عمليات التحضيرات الأوليـة وذلك لإكسـاب الأقهشة القطنيـة بياضـا لا يـزول أو يتحول إلى اللون الأصفر بهضى الوقت . والمواد المسببـة لهذه الألوان هى مركبـات عضوية معقدة يهكن تحليلها إلى مـواد بسيطلة تـذوب فيى الماء أو إلى مـواد أخرى لا لـون لها بتأثير المواد المؤكسلدة أو المواد

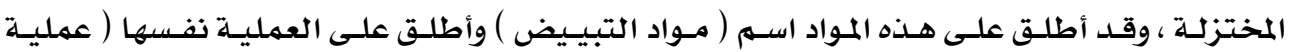
التبييض (

ومسن مـواد التبيـيض المؤكسلدة والتـى تستخدم على نطـاق واسـع فى مجــال الصنـاعة : مـادة فوق أكسيد الهيدروجـين ، وذلك لأن المواد المؤكسدة المستخدمـة فى عملية التبيـيض و المحتويـة على الكلور مثل : هيبوكلوريت الصوديوم ، كلوريت الصوديوم ثبـت تأثيرهـا الضـار على البيئسة والإنسـان .

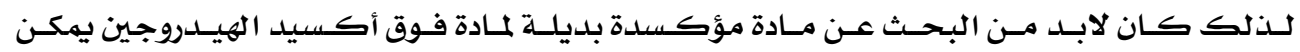
استخدامها فى حـالة وجود ما يعوق استخدام فوق أكسيد الهيدروجين مثل ارتفاع سعر الأكسجـين أو حظـر اسـتخدامـه حيـث أن الأكسسجين يـدخل في صسناعة المفرقعـات والمتفجـرات وأصسبح عليسه قيـودا

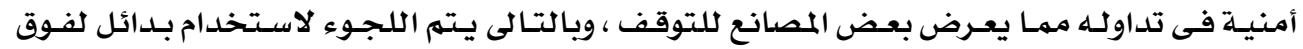

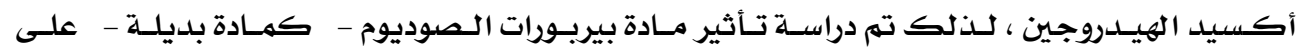
الخــواص الطبيعيـة والميكانيكيـة للقهـاش القطنـى المستخلدم ومقارنتهـا بتـأثيرالتبييض بهـادة فـوق

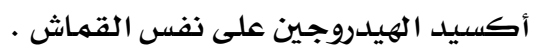

والقطن مـن أرخـ الخـامـات النسسجية فى مـصر وأكثرهـا استتخدامـا فى عدة مهــالات ، فيدخل فى صناعة الملابس ، المفروشات ، الجوارب ، السجـاد ،الأربطة الطبية ، الخيام ، المظلات وغيرها ، ويهتص القطن الرطوبـة بلدرجة عالية لذا تتوافر فيـه خاصية الراحة ويسهل صبياغته ، ويتحمل القطن عامـة المواد المؤكسدة إلا أنه ينبغى استخدلامها بعنايلة . ويعتبر مجـال المفروشات من المجالات الهامـة التى طرحت نفسها فى الآونة الأخيرة باعتبـارها

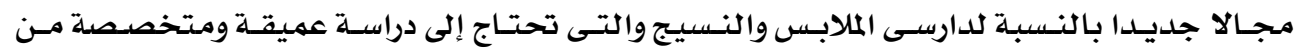

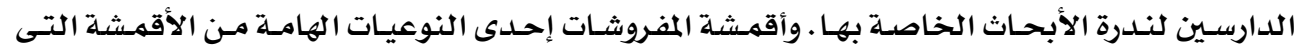


تقوم صناعة النسيج بإنتاجها وتقـديهها لجمهور المستهلكين وهى تحظى فى مجـال إنتاجها بجانب

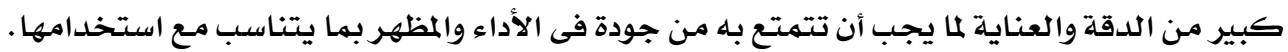
لذا كان إختيار موضوع البحث تحت عنوان " تأثير التبييض باستخدام بيربورات الصوديوم

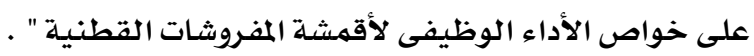

$$
\text { تكمن فى التساؤلات الأتية : }
$$

1- هل يؤثر تركيز مـادة بيربـورات الصوديوم على خـواص الأداء الـوظيفى لأقمشـة المفروشـات

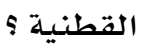

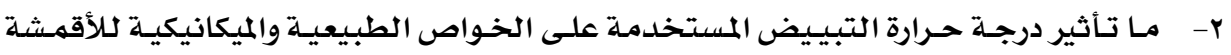

$$
\text { تحت البحثى مأبر }
$$

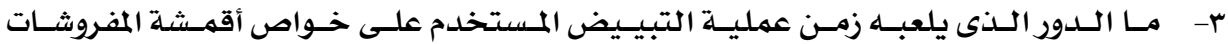
القطنية؟

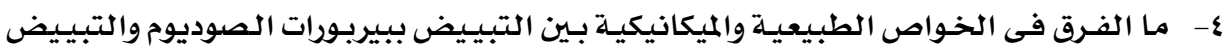

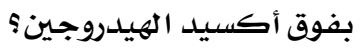

ه- هـل الأفضل لتجهيـز الأقمـشة للصبـاغة التبيـيض ببيربـورات الـصوديوم أم التبيـيض بفـوق

$$
\text { أكسيد الهيدروجين؟ }
$$

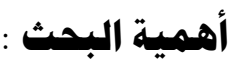

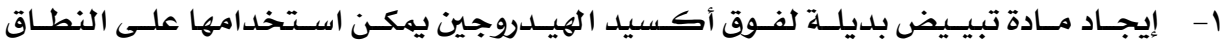

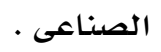

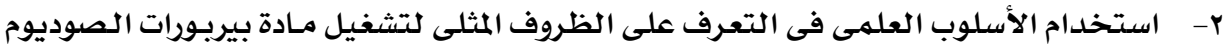

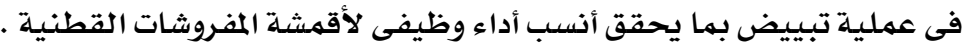

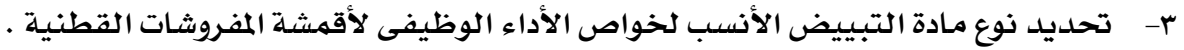

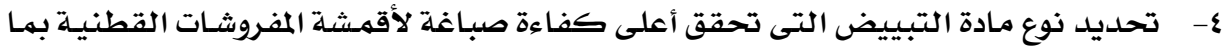

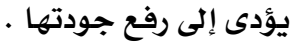

أهداف البحث :

ا - دراسـة تأثير تركيز مـادة بيربورات الصوديوم على خـواص الأداء الوظيفى لأقمشة المفروشـات

$$
\text { القطنية. }
$$

ץ- التعرف على تأثيردرجـةحرارة عمليةالتبييض المستخدمةعلى الخـواص الطبيعيلةوالميكانيكيـة

$$
\text { لبقوماش تحت البحث. }
$$

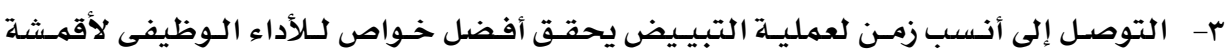

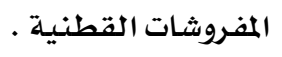




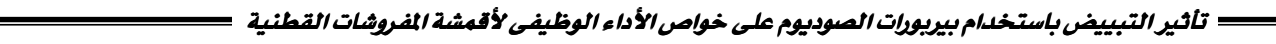
ع- التوصل إلى أنسب مادة تبييض تحقق أفضل تبييض للصباغة للقماش تحت البحث .

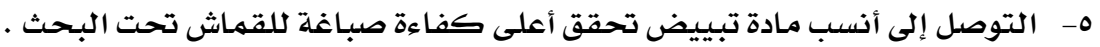

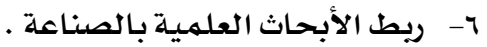

فروض البحث : ابط

1- توجد فروق ذات دلالة إحصائية بين تركيز مـادة التبييض المستخدمـة(بيريورات الصوديوم)

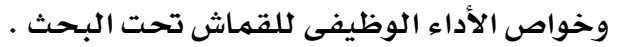

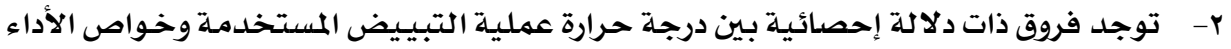
الوظيفى للقماث تحت البحث.

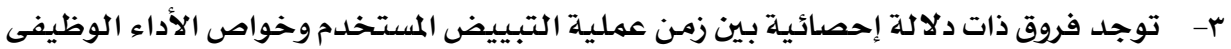

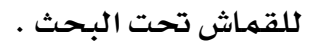

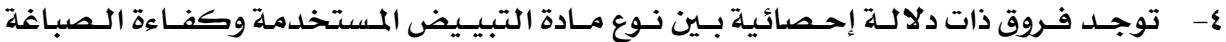
للقماش تحت البحث .

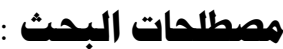
• التبييض : تـتم على الخامـات لإكسابها اللـون الأبـيض أو درجـة البيـاض المطلوبـة والتتخلص مـن لـون

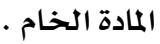

$$
\text { ( r...r : هدى محمد : (1) }
$$

\section{• بيربورات الصوديوم : أو فوق بورات الصوديوم NaBo3}

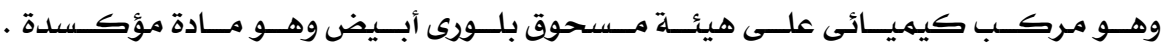

(http://www.marefa.org/index.php/) • خواص الأداء الوظيفى :

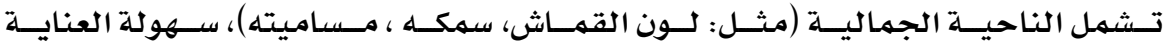

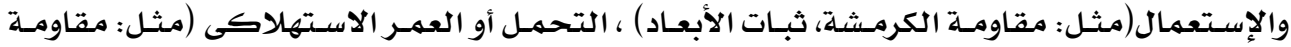

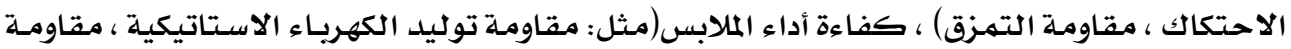

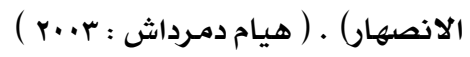
• المفروشات :

مصطلح يشتمل على جميع الأقمشـة المستخدمـة في كساء المقاعد والجدران وعمل الستائر

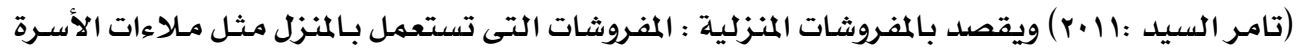

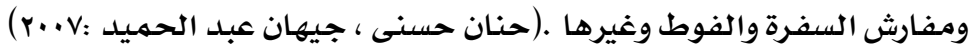




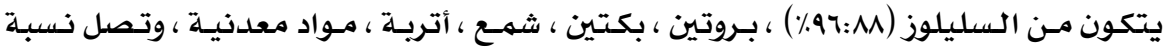

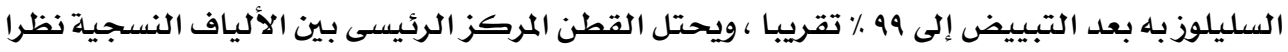

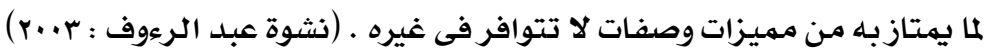

هدود البمث :

يقتصر هذا البحث على ما يلى :

1- مفروشات الأسرة ( وبخاصدة ملاءات الأسرة ، أكياس الوسائد )

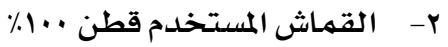

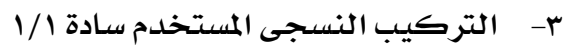

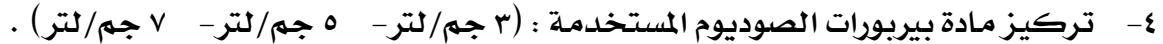

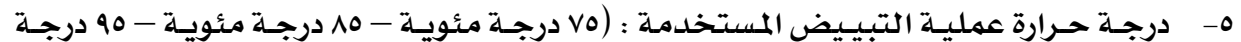

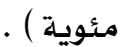

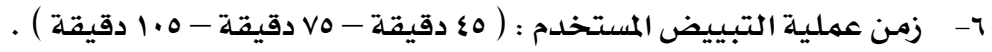

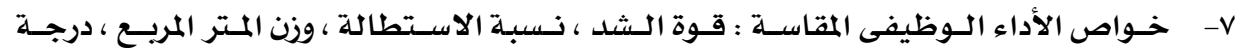

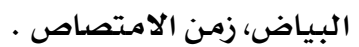

هنهفج البحث :

المنهج التجريبى التحليلى

\section{الدراسات السابقة:}

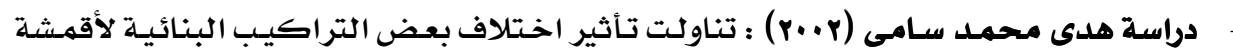

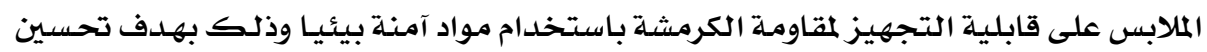

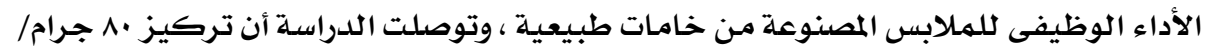

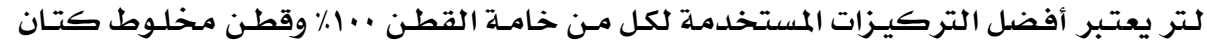

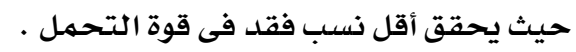

دراسة نشوة عبد الرووف (r..r) : تناولت تأثير بعض التراكيب البنائية للأقمشة السليلوزية

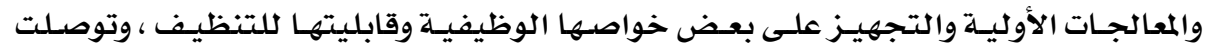

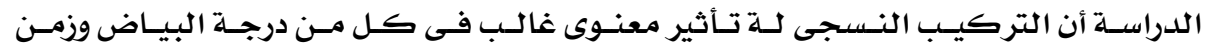

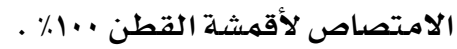

ولقد تم الاستفادة من تلك الدراسات فى تحديد المعالجات الأولية - وخاصة التبييض-

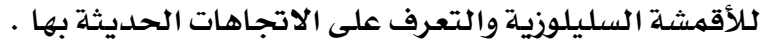




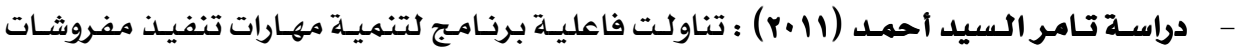

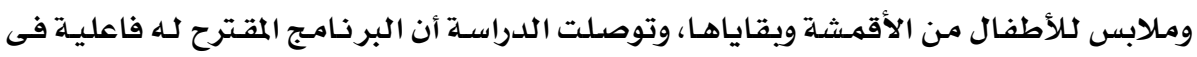

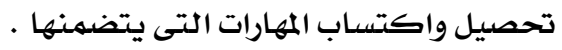

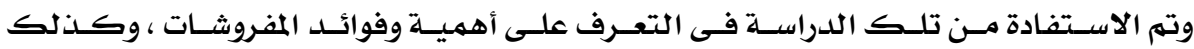

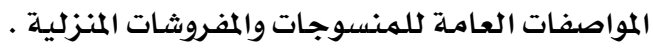

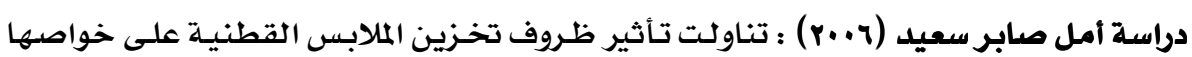

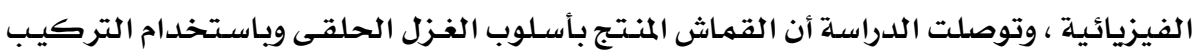

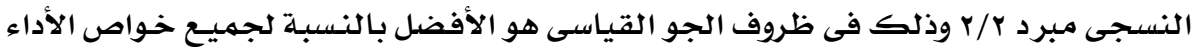
المختلفة .

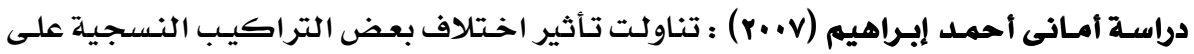

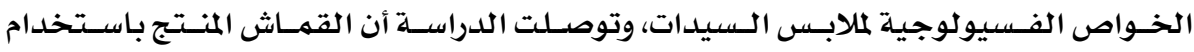

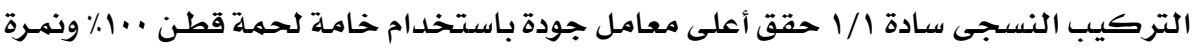

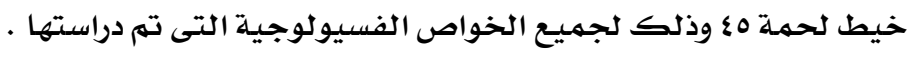
وتم الاستفادة من تلك الدراسـات فى تحديـ استعمالات القطن ومميـزات وعيوب الأقمشة القطنية .

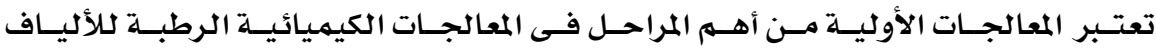

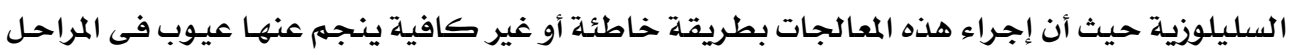

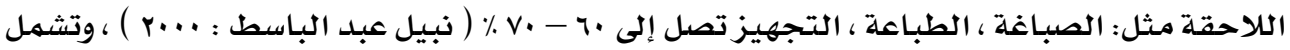

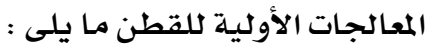

$$
\begin{aligned}
& \text { 1- حرق الوبرة . }
\end{aligned}
$$

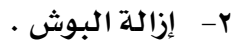

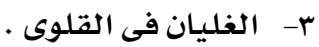

$$
\begin{aligned}
& \text { ع- التبييض • العليان } \\
& \text { ه- التحرير • ( أسماء سامى : r..v ) }
\end{aligned}
$$

يـتم فيـه التخلص مـن لـون القطـن الأصـلى وتحويلـه إلى اللـون الأبـيض الـدائم ، ويعتبر

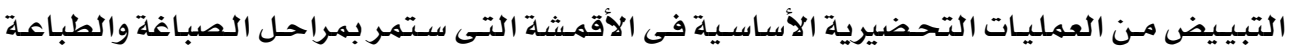

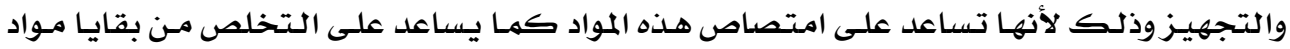

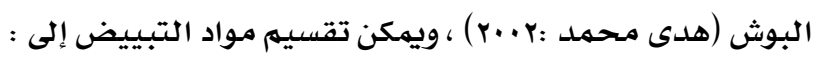

1- مواد تبييض مختزلة : تعتمد على تفاعل هذه المواد مـع الأكسجين الموجـود في الماء مكونـا

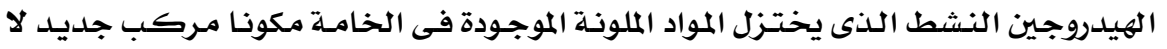




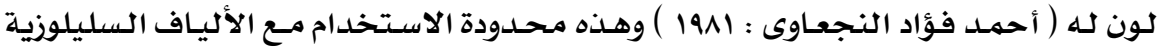

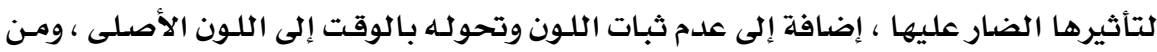

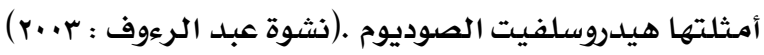

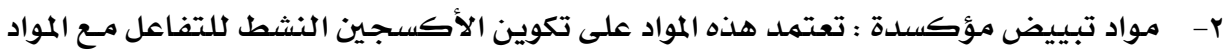

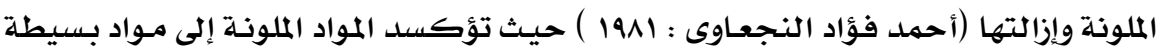

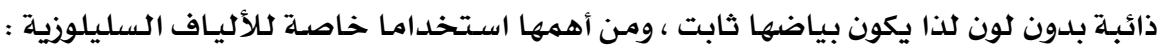

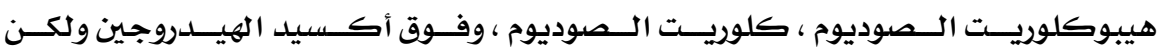

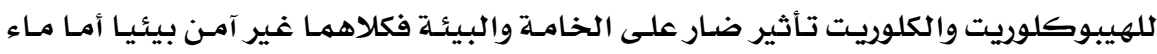

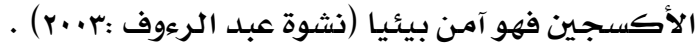

فوق أكسيد الهيدروجين

من أكثر الطرق الشائعة استخداما لمعالجة القطن والألياف الطبيعية الأخرى ويعتبر مـن

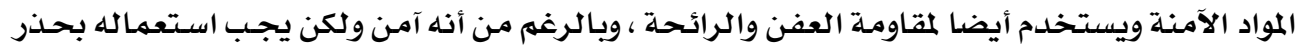

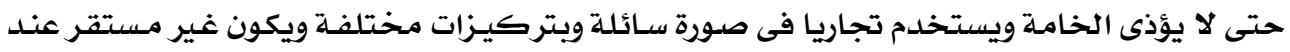

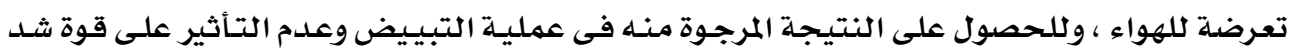

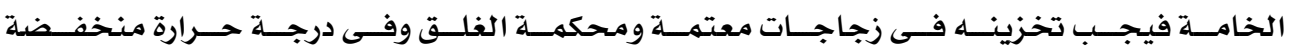

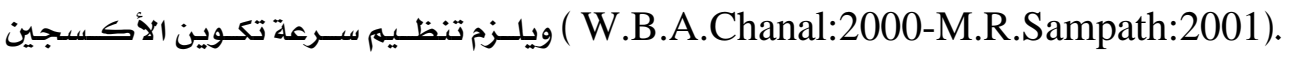

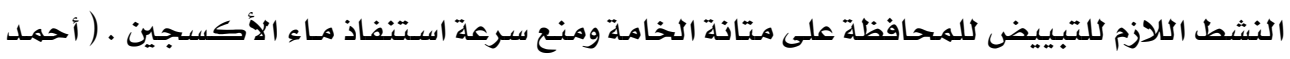

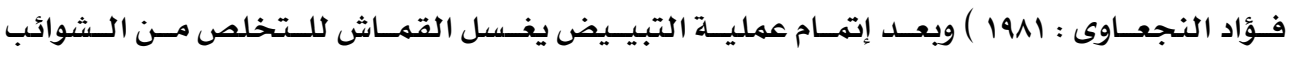

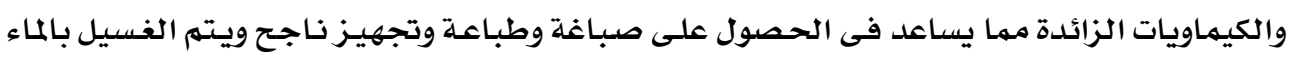

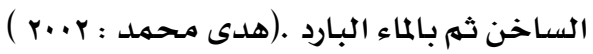

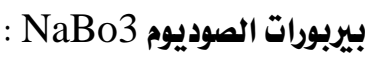

مادة مؤكسدة صيغتها الجزيئية NaBo3.n H2O وهى عبـارة عن بللورات شفافة أو بودرة

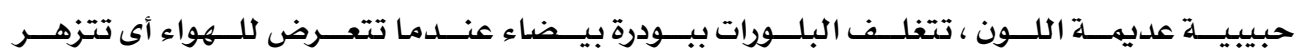
Effelorescence

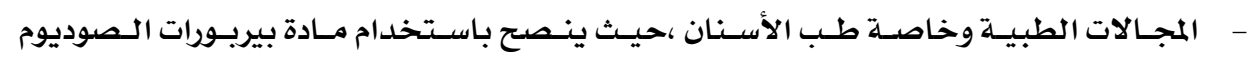

$$
\text { كغسول فم بسبب خواصها المطهرة . }
$$

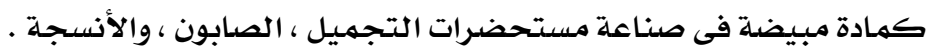

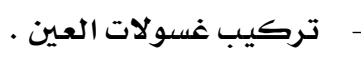

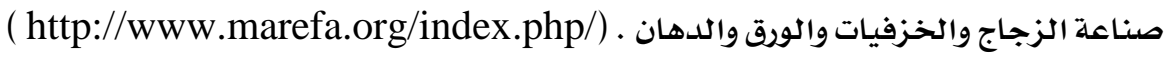

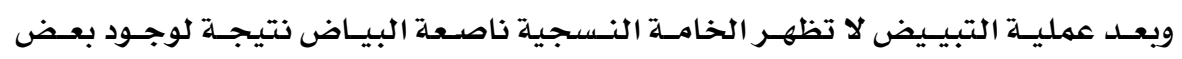

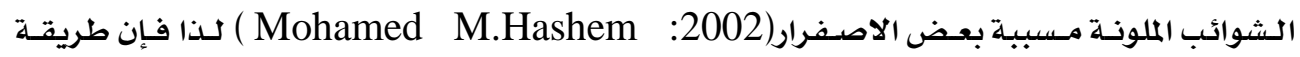
التبييض المناسبة تعتمد على درجة البياض المطلوبة تبعا للاستخدام النهائى كالتالى : 


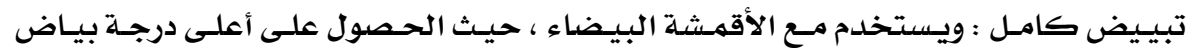

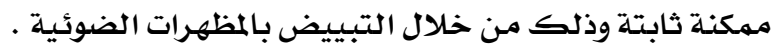

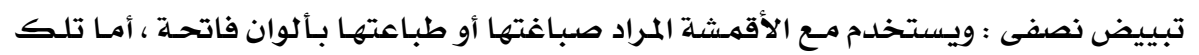

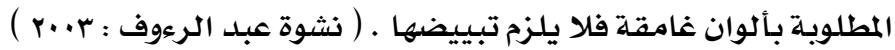

الاتجاهات الحلديثة فى عملية التبييض :

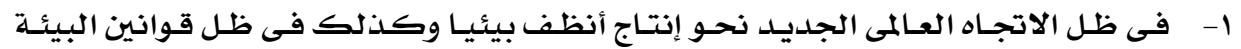

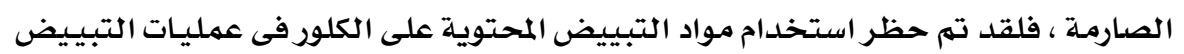

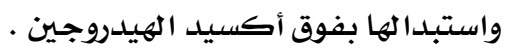

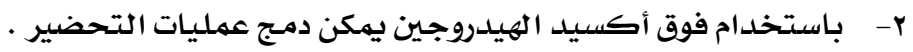

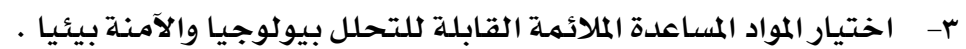

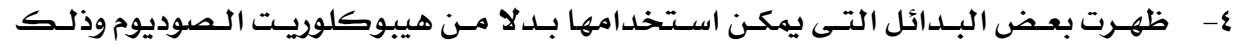

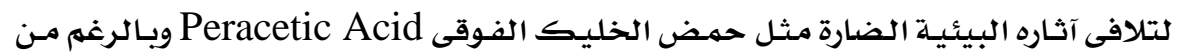

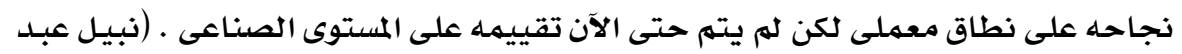

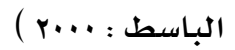

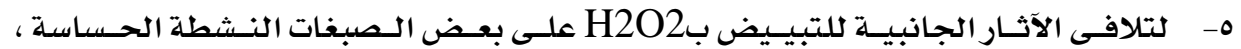

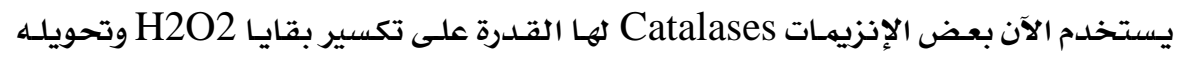

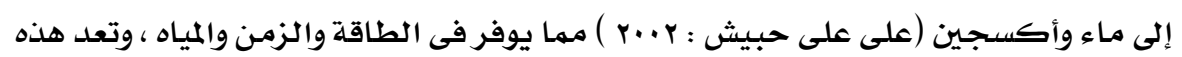
الطريقة أكثر صداقة للبيئة .

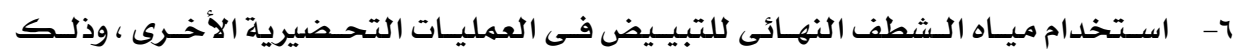

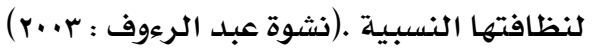

الإفروشات : الفئر

تعتبر المفروشات من الضروريات اللازممة لكل منزل لما لها من أهمية ووظيفة ، ويجب أن تكون

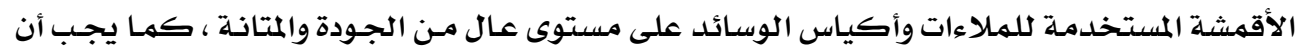

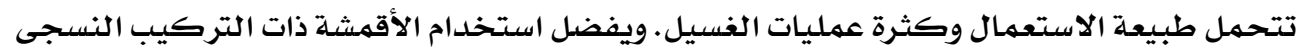

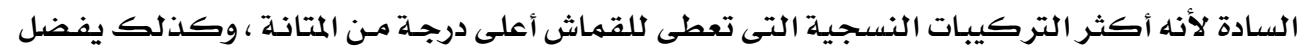

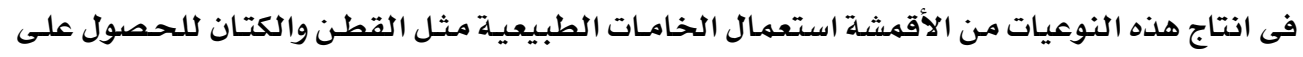

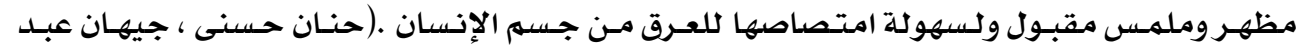

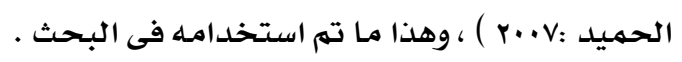

\section{التصنيف العام لأقشة المفروشات :}

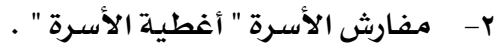

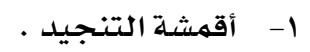

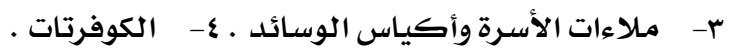

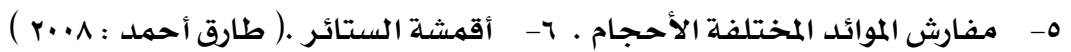




$$
\begin{aligned}
& \text { تتضـح أهمية وفوائد المفروشـات فى إعطاء ما يلى : } \\
& \text { 1- القيمة الجمالية من حيث التصميم - الشكل - اللون . }
\end{aligned}
$$

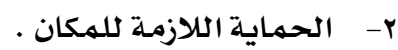

$$
\begin{aligned}
& \text { r- الدفء والراحة .( سـامية إبراهيم لطفى : ب..r ) } \\
& \text { 1- نوع الخامـة (قطن - كتان - حرير - صوف - مخلوط ) . }
\end{aligned}
$$

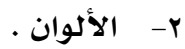

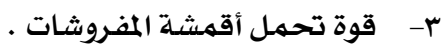

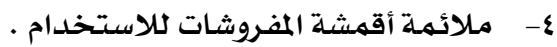

$$
\begin{aligned}
& \text { - - السعر والتكلفة .( تامر السيد : (1) ) }
\end{aligned}
$$

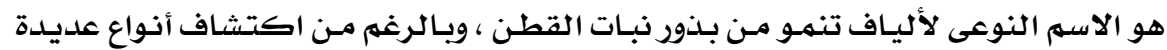
من الألياف الصناعية التى اتسع استخدامها الآن إلا أن القطن استطاع أن يحتفظ بهكانته وأهميتهـ

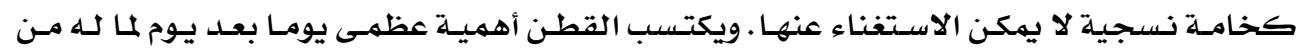

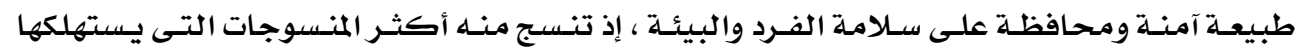

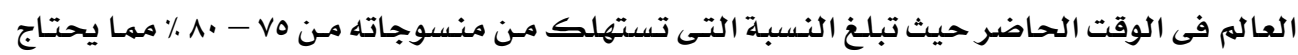

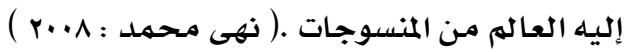
استخدامات القطن :

• يستخلدم بكثرة فى الملابس الخارجية ، ويصنع منـه ، 9 ٪ مـ الملابس الداخلية وملابس العمل . • يستخلدم فى عمل المفروشات والبطاطين والسجـاد . • يـمنع منــه القطـن الطبـى والغيـارات الطبيـة وملابسس الأطبـاء والممرضـات كسهولة التعقـيم والغلى .

\begin{tabular}{|c|c|c|c|}
\hline المتانة . & $-r$ & الراحة عند الاستعهمال . & -1 \\
\hline الخلو من الشحنـات الكهريية . & $-\varepsilon$ & الملائمسة للحجو . & 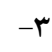 \\
\hline مرونة الأقمششة القطنيـة . & -7 & سهولة العناية . & -0 \\
\hline سهولة الصبـاغة والطباعة . & $-\wedge$ & سهولة إكسـابـه صفات جديدة . & $-\mathrm{V}$ \\
\hline ل اض سعر النتجات الق & -1 & نقص نسبـة الانكمـاش . & -9 \\
\hline
\end{tabular}

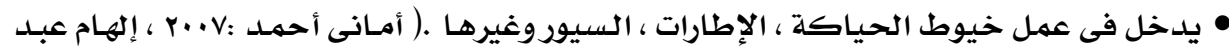

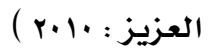

\section{ميزات الأقهشة القطنية :}




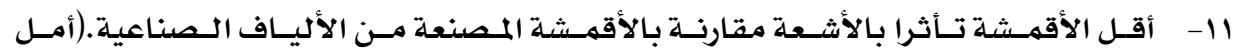

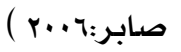

عيوب الأقمشة القطنية :

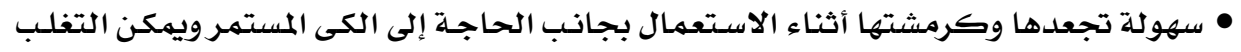

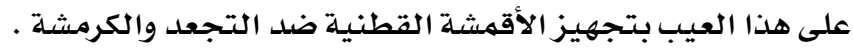

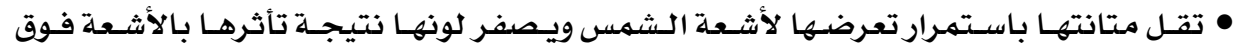

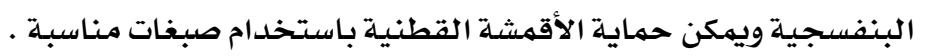

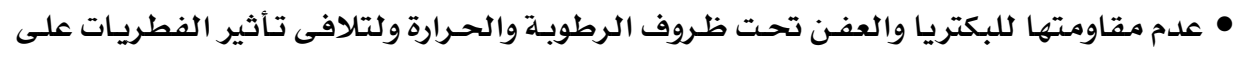

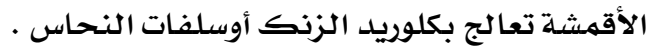

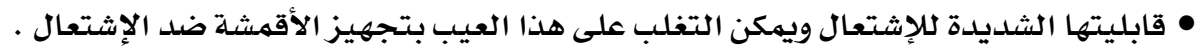

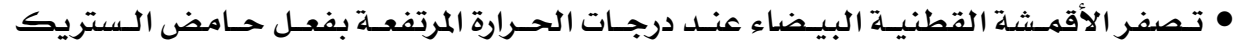

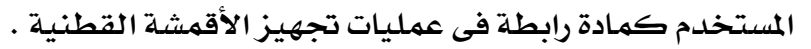

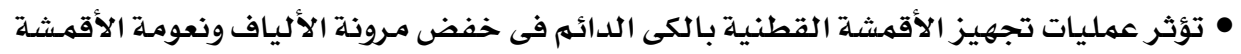

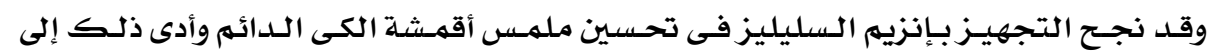

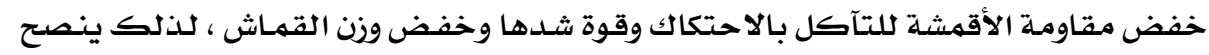

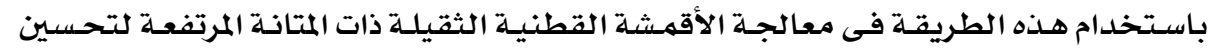
( أمل صابر : ( ب...7) الملمس باستخ

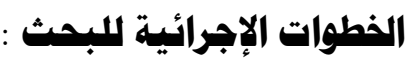

أولا: تم استخدام قماش صنف · م ه بالمواصفات الآتية :

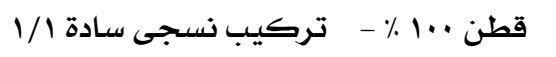

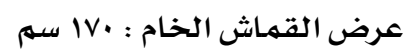

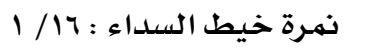

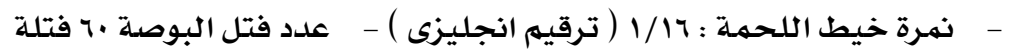

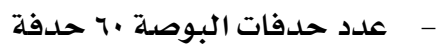

ويستخدم هذا القماش فى المفروشات وقد تم الحصول عليه من شركة مصريللغزل والنسيج بالمحلة الكبرى ثانيا : تم تبييض القماش تحت البحث بعد مرحلة الفليان فى القلوى وفقا للمتفيرات الآتية :

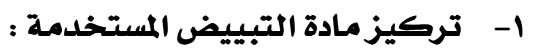

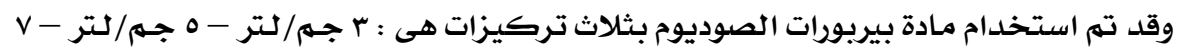

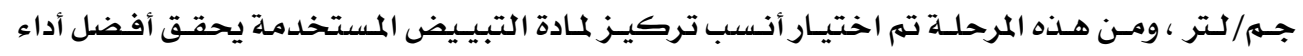




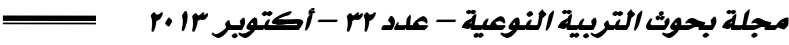

وظيفى للقماش تحت البحث وذلك مع ثبات درجة الحرارة عند V0 درجـة مئوية وزمن عملية التبييض عند 0؟ دقيقة .

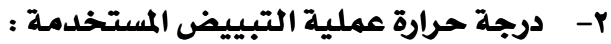

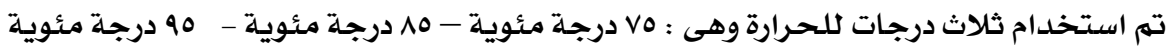

، ومن هذه المرحلة تم تحديد أنسب درجة حرارة لعملية التبييض تحقق أفضل قيم للخـواص المقاسـة ،

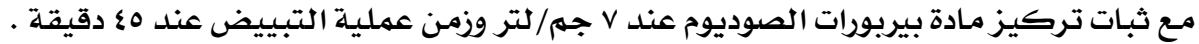

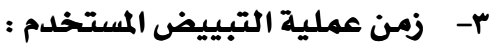

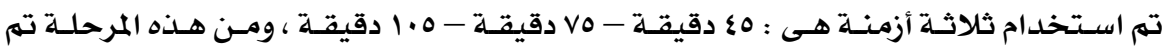

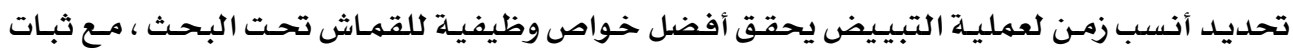

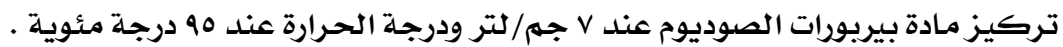

وقبل كل مرحلة من المراحل الثلاث السابقة كانت تغسل العينات بالماء الجـارى لإزالـة مـواد

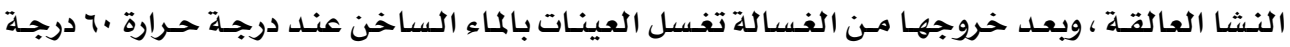

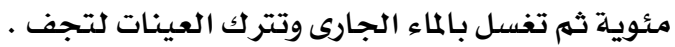

ثالثا : تم تبييض القماش تحت البحث بعد مرحلة الفليان فى القلوى بمادة التبييض المستخدمة فى شـركة مسر

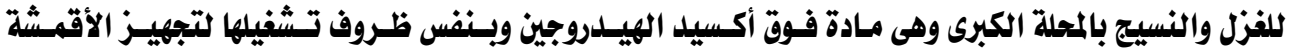

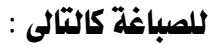

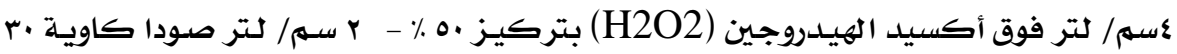

بومياه .

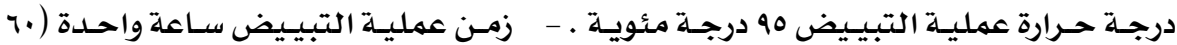

دقيقة ).

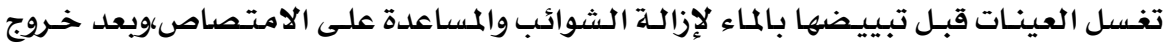

العينات من الغسالة تغسل بالماءالجارى وتترك لتجف.وقد تم عمل هذه العينـات لمقارنتها بعينـات مـادة

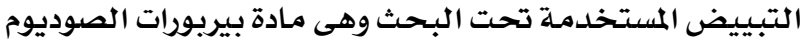

رابعا : تم إجراء الاختبارات المعملية وقد شملت ما يلى :

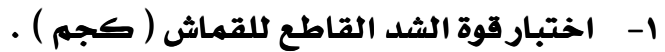

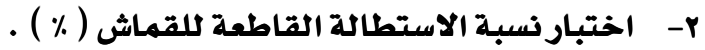

وقد تم إجراء اختبارات قوة الشد ونسبة الاستطالة طبقا للمواصفات القياسية المصرية رقم

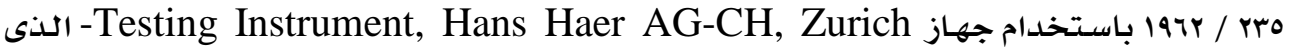
يعمل بطريقة المعدل الثابت للسرعة . 


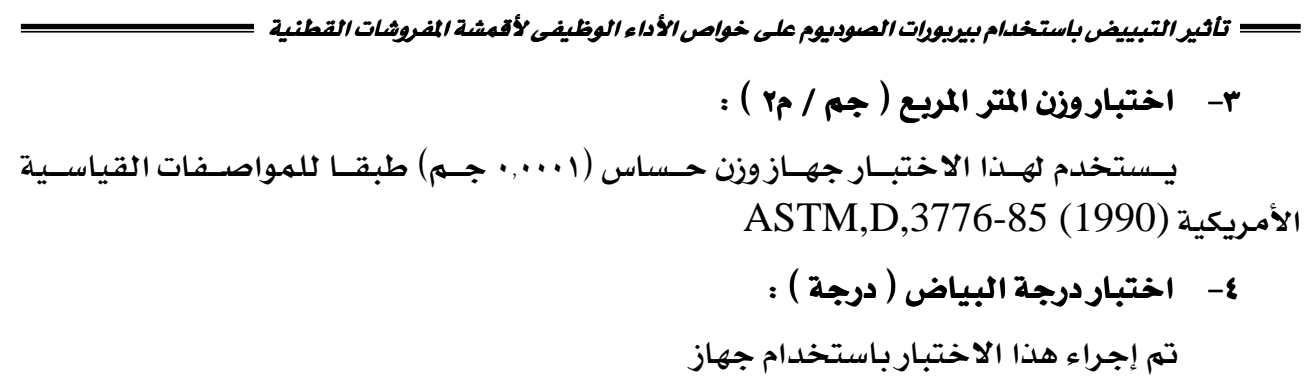

-Data Color / Spectro Photometer, SF 600+, Data Color International 1994, U.S.A.

$$
\text { ه- اختبارزمن الامتصاص ( ثانية ) : }
$$

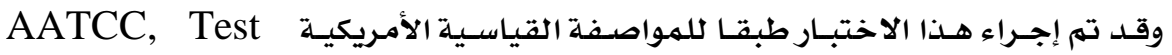

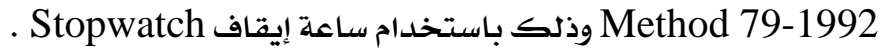

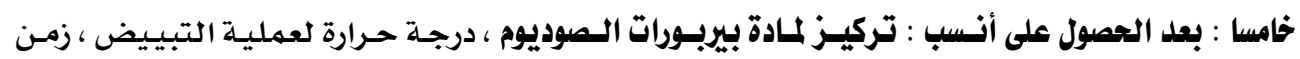

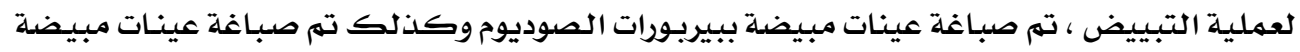

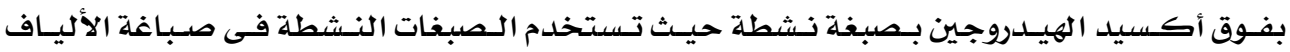

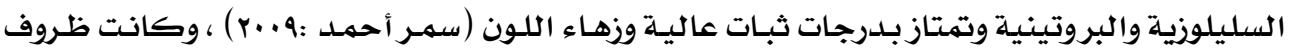
التشغيل كما يلى :

- Reactive Blue-

- Shade $1 \%$

- L.R. 1: 40

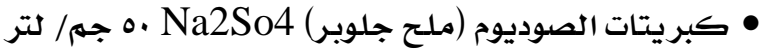

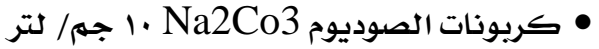

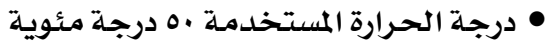

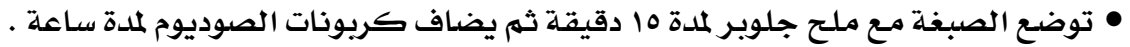

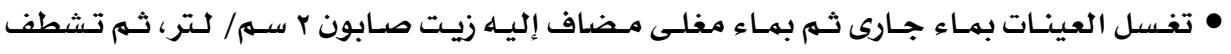

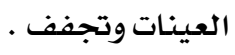

سادسا: تم قياس الاختبارات الآتية على العينات المصبوغة والمبيضة سـواء ببيربـورات السصوديوم أو فـوق أكسيد الهيلدروجين :

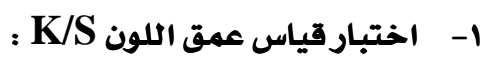

Spectro Photometer,Data Colour International Model تم استخدام جهاز

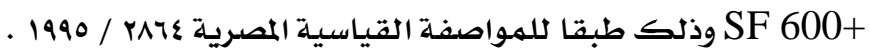




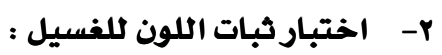

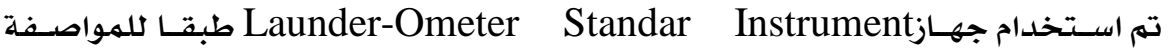
القياسية 1975- وتم تقييم العينـات بالمقياس الرمـادى AATCC Test Method . Scale

$$
\text { r- اختبار ثبات اللون للاحتكاك ( جاف - رطب ) : }
$$

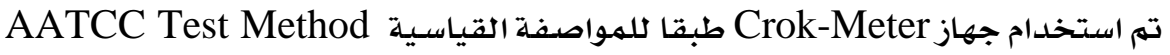

1977- 8 وتم تقييم مدى التغير في لون العينات باستخدام المقياس الرمادى Gray Scale.

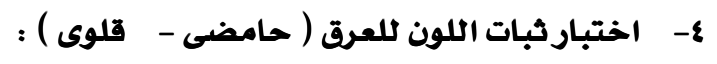

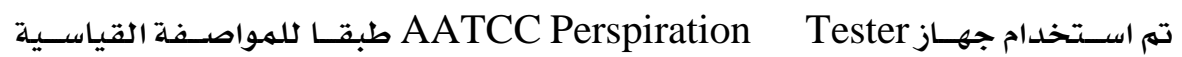

Gray وتم تقييم العينات باستخدام المقياس الرممادى AATCC Test Method 15-1973 . Scale

$$
\text { 0- اختبار ثبات اللون للضوءء : }
$$

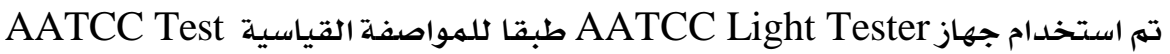

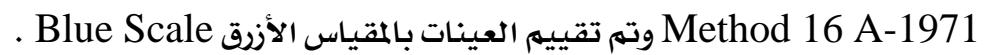

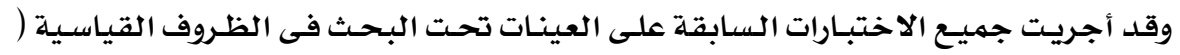

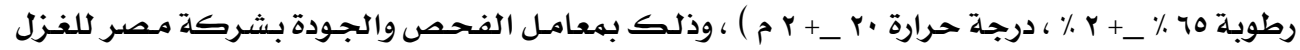

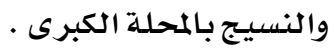

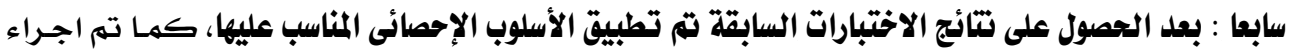

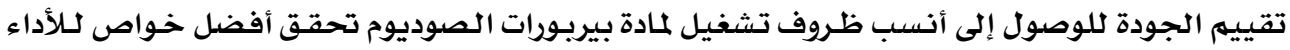

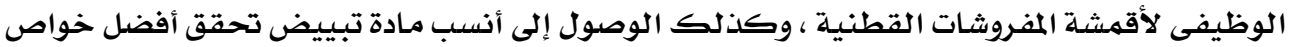

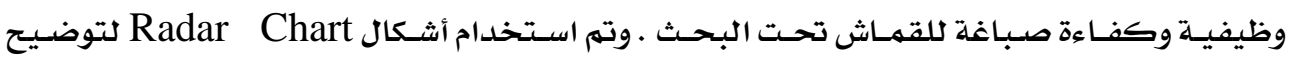

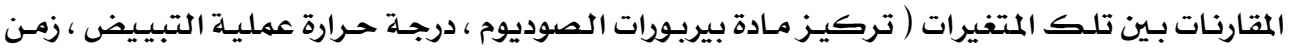

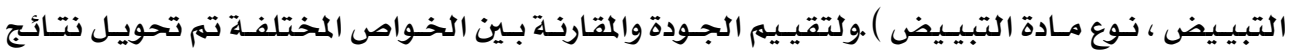

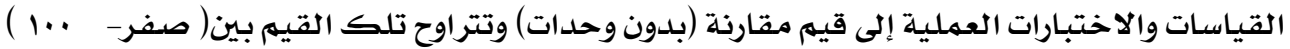

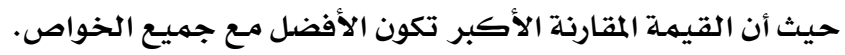

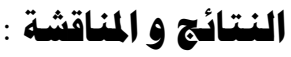

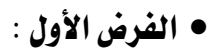

توجد فروق ذات دلالة إحصائية بين تركيز مادة التبييض المستخدمة (بيربورات الصوديوم)

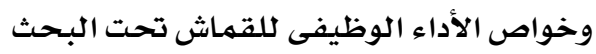


لـ تأثير التبييض باستخدام بيريورات الصوديوم على خواص الأداء الوظيفى لأقهشة المفروشات القطنية • نتائج خواص الأداء الوظيفى لعينات القماش قبل مرحلة التبييض : جدول (1) متوسطات نتائج خواص الأداء الوظيفى لعينات القماش بعد مرحلة الغليان فى القلوى (قبل التبييضي (1)

\begin{tabular}{|c|c|c|c|c|c|c|c|}
\hline \multirow{2}{*}{ زمن الإمتصاص } & \multirow[t]{2}{*}{ درجة البياض ( ) ) } & \multirow{2}{*}{ وزن المتر المربع } & \multicolumn{2}{|c|}{ نسبة الإستطالة \% } & \multicolumn{2}{|c|}{ قوة الشد (كجم ) } & \multirow{2}{*}{ نوع العينة } \\
\hline & & & لدمة & سلداء & لحمة & سلداs & \\
\hline 7. & _ זr & $r \cdot 0, r$ & $r v, 0$ & 19,0 & VA & 99 & عينات القماش قبل \\
\hline
\end{tabular}

• نتائج الخواص الطبيعية والميكانيكية لعينات القماش تحت البحث :

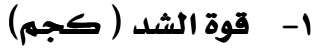
أولا : قوة الشد فى اتجـاه السداء:

جلدول (r) تحليل التباين لتأثير اختلاف تركيز مادة التبييض المستخدمة على قوة الشد في اتحاه السداء

\begin{tabular}{|c|c|c|c|c|c|}
\hline الدلالة & قيمة (ف) & درجات الحرية & متوسط المربعات & مجموع المربعات & سلداء \\
\hline \multirow{3}{*}{0.0101} & \multirow{2}{*}{18.622} & 3 & 4433.000 & 13299.000 & بين المججموعات \\
\hline & & 8 & 238.050 & 1904.400 & داخل المجهوعات \\
\hline & & 11 & & 15203.400 & المجموع \\
\hline
\end{tabular}

يتضح من جدول (r) أن قيمـة ( ف) )كانت (18.622) وهى قيمـة دالة إحصائيا عند مستوى

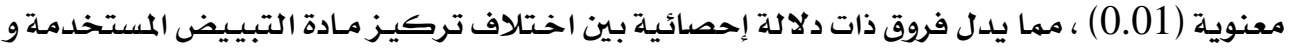
قوة الشد فى اتجاه السداء، ولمعرفة اتجاه الدلالة تم تطبيق اختبـار LSD للمقارنات المتعددة والجـدول التالي يوضـح ذلك : جدول ( ب ) اختبار LSD للمقارنات المتعددة لتأثير اختلاف تركيز مـادة التبييض المستخدمة على قوة الشد

\begin{tabular}{|c|c|c|c|c|}
\hline \multicolumn{5}{|c|}{ في اتجـاه السـداء } \\
\hline 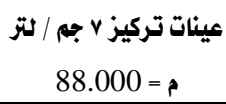 & 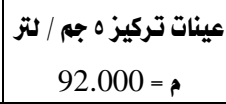 & 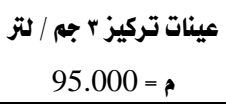 & 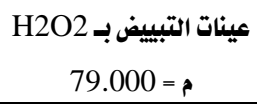 & 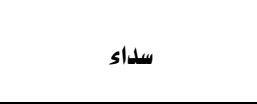 \\
\hline & & & & عينات التبييض بـ H2O2 \\
\hline & & & $* * 16.000$ & عينات تركيز ب جم / لتر \\
\hline & & $* * 3.000$ & $* * 13.000$ & عينات تركيز 0جم / لتر \\
\hline & $* * 4.000$ & $* * 7.000$ & $* * 9.000$ & عينات تركيز V جم / لتر \\
\hline
\end{tabular}

$$
\begin{aligned}
& \text { ** معنوى عند مستوى( } 1 \text { (., ) ). } \\
& \text { حيث أن: } \\
& \text { - غير معنوى منوى - } \\
& \text { م متتوسط النتائج } \\
& \text { * معنوى عند مستوى (0. . . ). }
\end{aligned}
$$




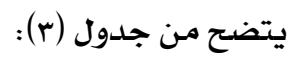

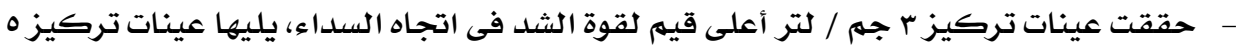

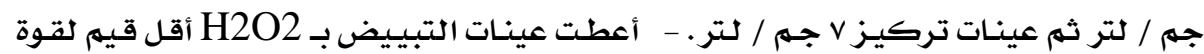

$$
\text { الشد فى اتجاه السداء. }
$$

ثانيا : قوة الشد فى اتجاه اللحمة :

\begin{tabular}{|c|c|c|c|c|c|}
\hline الدلالة & قيمة (ف) & درجات الحرية & متوسط المربعات & مجموع المربعات & لحمة \\
\hline \multirow{3}{*}{0.01 دال } & \multirow{2}{*}{19.994} & 3 & 4459.417 & 13378.250 & بين المجموعات \\
\hline & & 8 & 223.036 & 1784.287 & داخل المججموعات \\
\hline & & 11 & & 15162.537 & المجموع \\
\hline
\end{tabular}

جدول (ع) تحليل التباين لتأثير اختافلاف تركيز مادة التبييض المستخدمة على قوة الشد في اتجاه اللحمة

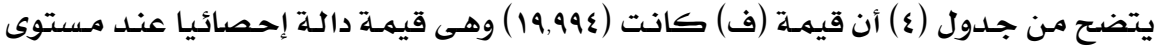

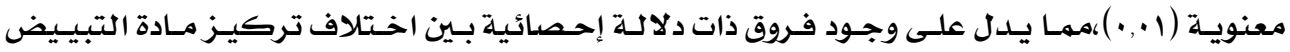

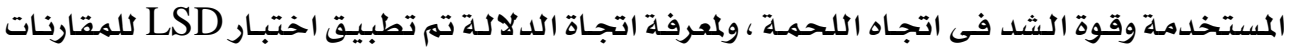

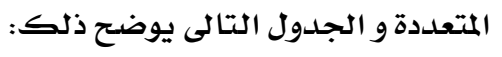

\begin{tabular}{|c|c|c|c|c|}
\hline \multicolumn{5}{|c|}{ في اتجاه اللحمـة } \\
\hline 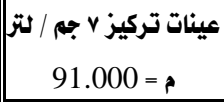 & عينات تركيز ه جم / لتر & عينات تركيز ب جم / لتر & | عينات التبييض بـ & لحمة \\
\hline & & & & عينات التبييض بـ H2O2 \\
\hline & & & $* * 12.000$ & عينات تركيز ب جم / لتز \\
\hline & & $* 2.000$ & $* * 10.000$ & عينات تركيز هجم / لتر \\
\hline & $* * 3.000$ & $* * 5.000$ & $* * 7.000$ & عينات تركيز V جه / لتر \\
\hline
\end{tabular}

جدول ( ه ) اختبار LSD للمقارنات المتعددة لتأثيراختلاف تركيز مادة التبييض المستخدمة على قوة الشد

$$
\text { يتضح من جدول (0) أن : }
$$

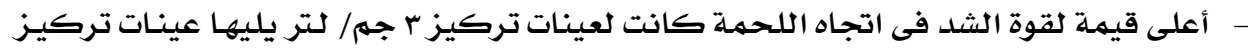

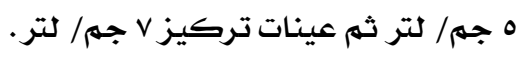

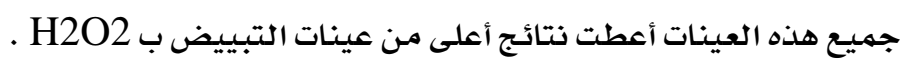

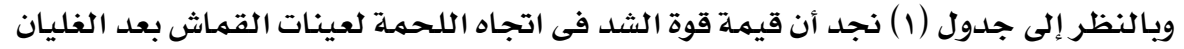

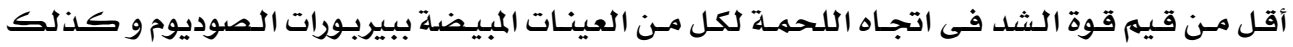

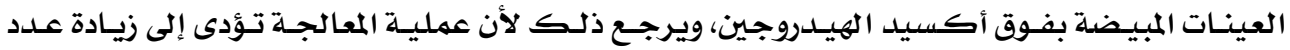

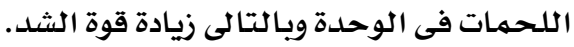


جدول ( 7 ) تحليل التباين لتأثير اختلاف تركيز مادة التبييض المستخدمة على نسبة الاستطالة

في اتجاه السداء

\begin{tabular}{|c|c|c|c|c|c|}
\hline الدلالة & قيمة (ف) & درجات الحرية & متوسط المربعات & مجموع المربعات & سلداء \\
\hline \multirow{3}{*}{0.01 داJ } & \multirow{2}{*}{10.286} & 3 & 183.354 & 550.063 & بين المجموعات \\
\hline & & 8 & 17.826 & 142.607 & داخل المجموعات \\
\hline & & 11 & & 692.670 & المجموع \\
\hline
\end{tabular}

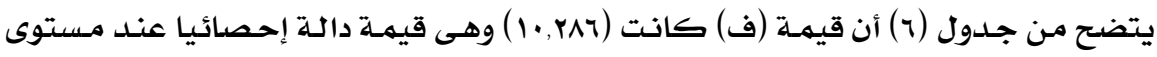

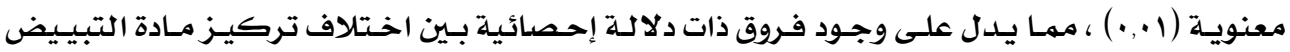

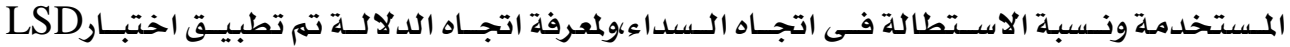

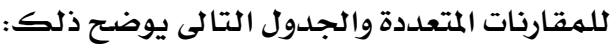

جدول(v) للمقارنات المتعددة لتأثير اختلاف تركيز مادة التبييض المستخدمة على نسبة الاستطالة في اتجاه السداء

\begin{tabular}{|c|c|c|c|c|}
\hline 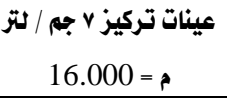 & عينات تركيز 0جم / لتر & 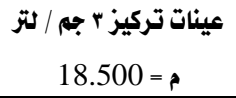 & 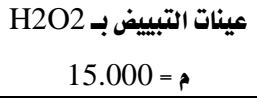 & سلداء \\
\hline & & & & عينات التبييض بـ H2O2 \\
\hline & & & $* * 3.500$ & عينات تركيز ب جم / لتر \\
\hline & & $* * 1.500$ & $* * 2.000$ & عينات تركيز 0جم / لتر \\
\hline & $* 1.000$ & $* * 2.500$ & $* 1.000$ & عينات تركيز V جم / لتر \\
\hline
\end{tabular}

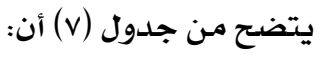

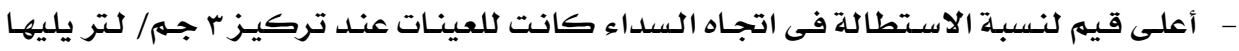

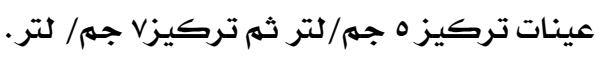

- العينات المبيضة بH2O2 أعطت أقل قيم لنسبة الاستطالة في اتجاه السداء ل

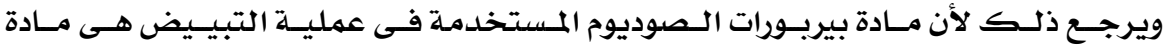

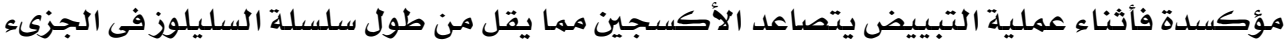
وبالتالى تقل نسبـة الاستطالية. 
ثانيا : نسبـة الاستطالة فى اتجاه اللحمهة جلدول ( ^ ) تحليل التبـاين لتأثير اختافلاف تركيز مـادة التبييض المستخدمة على نسبـة الاستطالة فى اتجاه اللححمـة

\begin{tabular}{|c|c|c|c|c|c|}
\hline الدلالة & قيمة (ف) & درجات الحرية & متوسط المربعات & مجموع المربعات & لحمة \\
\hline \multirow{3}{*}{0.01 دال } & \multirow{2}{*}{8.732} & 3 & 273.917 & 821.750 & بين المجموعات \\
\hline & & 8 & 31.371 & 250.967 & داخل المجموعات \\
\hline & & 11 & & 1072.717 & المجموع \\
\hline
\end{tabular}

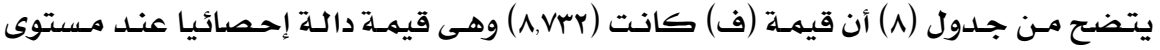

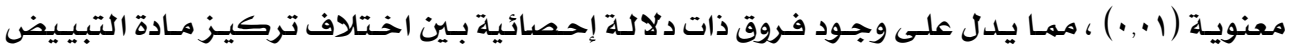

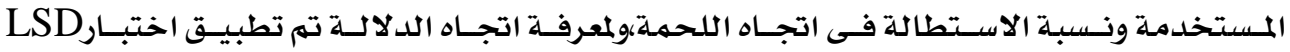

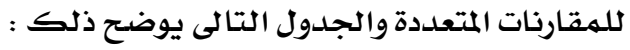
جلدول(q) اختبار LSD للمقارنات المتعددة لتأثير اختلاف تركيز مادة التبييض المستخدمة على نسبة الاستطالة في اتجاه اللحمة

\begin{tabular}{|c|c|c|c|c|}
\hline 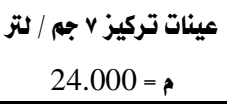 & 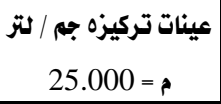 & 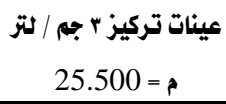 & 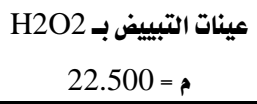 & لحمة \\
\hline & & & & عينات التبييض بـ H2O2 \\
\hline & & & $* * 3.000$ & عينات تركيز ب جم / لتر \\
\hline & & $* 0.500$ & $* * 2.500$ & عينات تركيز هجم / لتر \\
\hline & $* 1.000$ & $* * 1.500$ & $* * 1.500$ & عينات تركيز V جم / لتر \\
\hline
\end{tabular}

$$
\text { يتضح من جدول (q) أن: }
$$

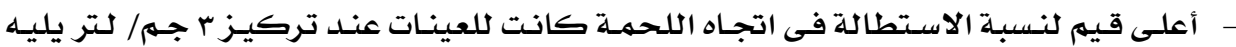

$$
\text { تركيز ه جم/ لتر ثم عينات تركيز V جم/ لتر . }
$$$$
\text { جميع هذه العينات أعطت نتائج أعلى من عينات التبييض بH2O2. }
$$

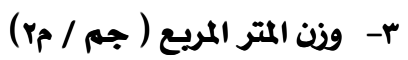

\begin{tabular}{|c|c|c|c|c|c|}
\hline الدلالة & قيمة (ف) & درجات الحرية & متوسط المربعات & مجموع المربعات & وزن المتر المربع \\
\hline \multirow{3}{*}{0.01 داנ } & \multirow{2}{*}{12.483} & 3 & 377.600 & 1132.800 & بين المجهوعات \\
\hline & & 8 & 30.250 & 242.000 & داخل المجموعات \\
\hline & & 11 & & 1374.800 & المجموع \\
\hline
\end{tabular}

جلدول ( • 1 ) تحليل التباين لتأثير اختلاف تركيز مادة التبييض المستخدمـة على وزن المتر المربع 


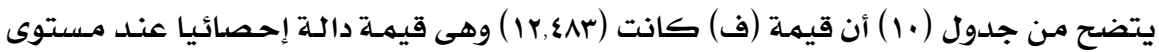

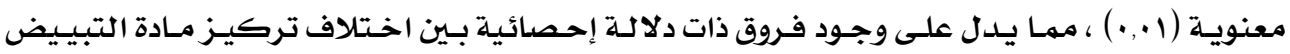

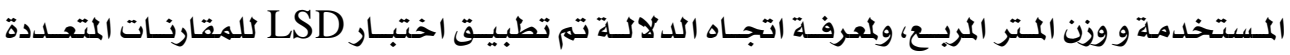
والجدول التالى يوضـح ذلك :

جدول ( 11 ) اختبار LSD للمقارنات المتعددة لتأثير اختلاف تركيز مادة التبييض المستخدمة على وزن المتر المربع

\begin{tabular}{|c|c|c|c|c|}
\hline 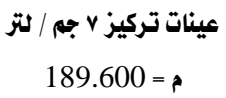 & 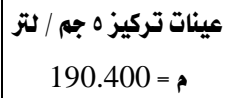 & 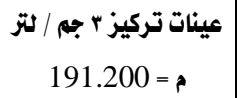 & 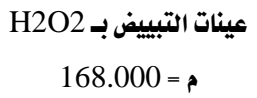 & وزن المتر المربع \\
\hline & & & & عينات التبييض بـ H2O2 \\
\hline & & & $* * 23.200$ & عينات تركيز ب جم / لتر \\
\hline & & -0.800 & $* * 22.400$ & عينات تركيز 0جم / لتر \\
\hline & -0.800 & $* 1.600$ & $* * 21.600$ & عينات تركيز V جم / لتر \\
\hline
\end{tabular}

$$
\text { يتضح من جدول (11) أن : }
$$

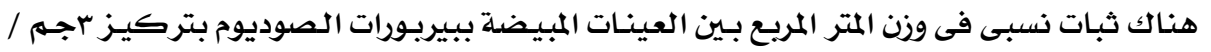

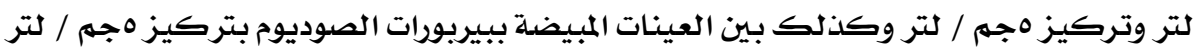

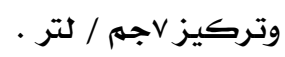

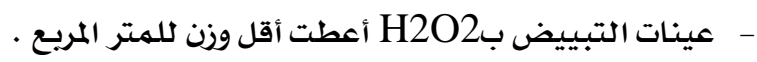

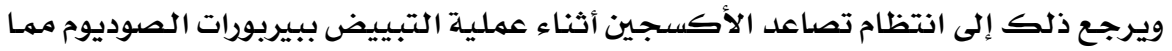

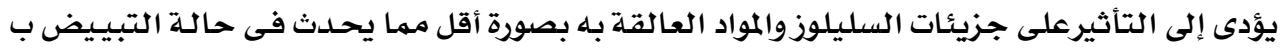

. $\mathrm{H} 2 \mathrm{O} 2$

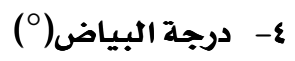

\begin{tabular}{|c|c|c|c|c|c|}
\hline الدلالة & قيمة (ف) & درجات الحرية & متوسط المربعات & مجموع المربعات & درجة البياض \\
\hline \multirow{3}{*}{0.01 دال } & \multirow{2}{*}{24.929} & 3 & 341.417 & 1024.250 & بين المجموعات \\
\hline & & 8 & 13.696 & 109.567 & داخل المججموعات \\
\hline & & 11 & & 1133.817 & المجموع \\
\hline
\end{tabular}

جلدول (r ا)تحليل التباين لتأثير اختالاف تركيز مادة التبييض المستخلمة على درجة البياض

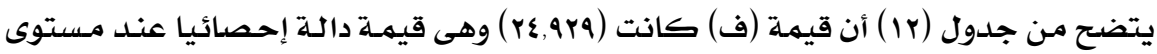

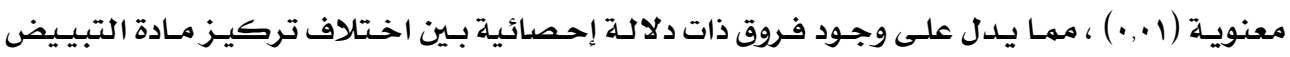

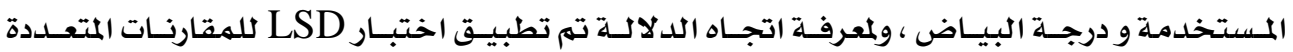
والجدول التالى يوضح ذلك درجة الئل 
جلدول (rا) اختبار LSD للمقارنات المتعددة لتأثير اختافلاف تركيز مـادة التبييض المستخدمـة على درجة البياض

\begin{tabular}{|c|c|c|c|c|}
\hline 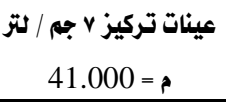 & 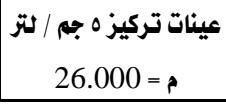 & 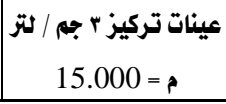 & 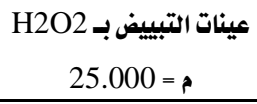 & درجة البياض \\
\hline & & & & عينات التبييض بـ H2O2 \\
\hline & & & $* * 10.000$ & عينات تركيز ب جم / لتر \\
\hline & & $* * 11.000$ & $* 1.000$ & عينات تركيز 0جم / لتر \\
\hline & $* * 15.000$ & $* * 26.000$ & $* * 16.000$ & عينات تركيز V جم / لتر \\
\hline
\end{tabular}

$$
\text { يتضح من جدول (rا ) أن : }
$$

- عينـات تركيـز V جـم// لـتر حققـت أعلى قـيم لدرجـة البيـاض،فكلهـا زاد تركيـز مـادة بيربـورات الـصوديوم كلهـا زادت درجـة البيـاض، ويـلاحسـ تقــارب درجــة البيـاض بـين عينـات تركيـز ه

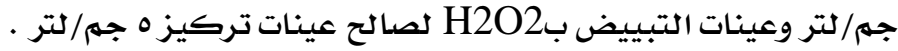
- عينات تركيز باجهم / لتر أعطت أقل درجـة بياض .

وبـالنظر إلى جـــول (1 ) نلاحسظ الفـرق الواضـح فى درجـة البيـاض بـين عينـات القهـاث بعـد

$$
\text { م- مرحلة الغليان فى القلوى (قبل التبييض) وعينات تركيز V جم/ لتر · }
$$

\begin{tabular}{|c|c|c|c|c|c|}
\hline اللدلالة & قيمة (ف) & درجات الحرية & متوسط المربعات & مجموع المربعات & الامتصاص \\
\hline \multirow{3}{*}{0.01 دال } & \multirow{2}{*}{30.633} & 3 & 834.750 & 2504.250 & بين المجموعات \\
\hline & & 8 & 27.250 & 218.000 & داخل المججموعات \\
\hline & & 11 & & 2722.250 & المجموع \\
\hline
\end{tabular}

جدول (ـا (تحليل التباين لتأثير اختلاف تركيز مادة التبييض المستخدمة على زمـن الامتصاص

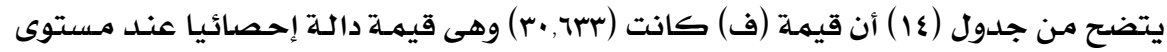

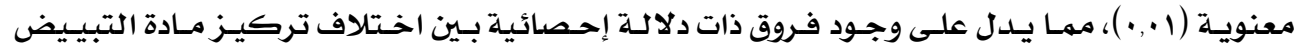

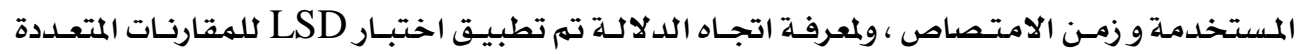
والجدول التالى يوضتح ذلك : 
جدول(10) اختبار LSD للمقارنات المتعددة لتأثير اختلاف تركيز مادة التبييض المستخدمة على زمن الامهتصناص

\begin{tabular}{|c|c|c|c|c|}
\hline | & 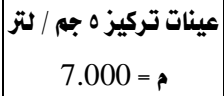 & 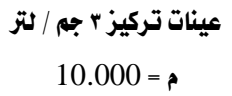 & |عينات التبييض بـ & الامة \\
\hline & & & & عينات التبييض ب H2O2 \\
\hline & & & $* * 35.000$ & عينات تركيز ب جم / لتر \\
\hline & & $* * 3.000$ & $* * 38.000$ & عينات تركيز هجم / لتر \\
\hline & $* * 3.000$ & $* * 6.000$ & $* * 41.000$ & عينات تركيز V جم / لتر \\
\hline
\end{tabular}

$$
\text { يتضح من جدول (10) أن : }
$$

- أعلى زمن للامتصاص كان لعينات التبييض بـ2O2

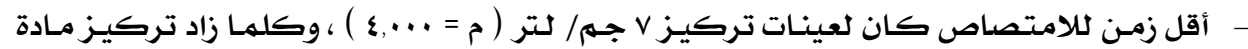

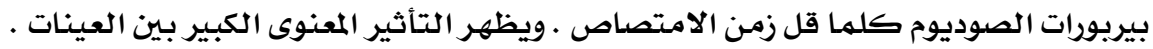

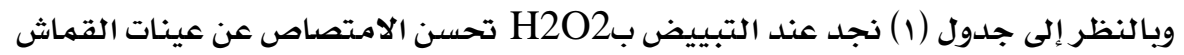

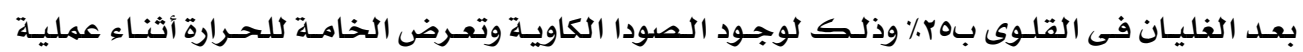

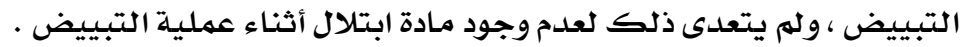

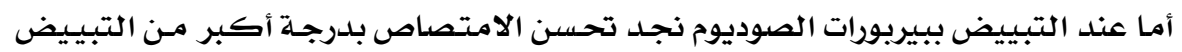

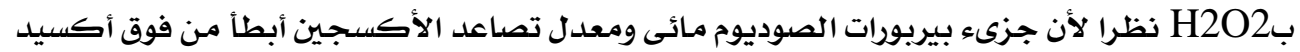

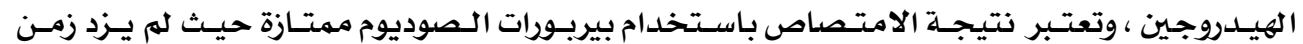

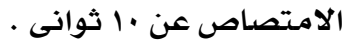

• تقييم الجودة لتأثير تركيز مادة بيريورات الصوديوم على خواص الأداء الكوظيفى للقماش تحـت الببحث : جدول رقم (1 ا ) تقييم الجودة لتأثير اختلاف تركيز مادة بيربورات الصوديوم على خواص الأداء الوظيفي

\begin{tabular}{|c|c|c|c|c|c|c|c|c|c|}
\hline \multicolumn{10}{|c|}{ 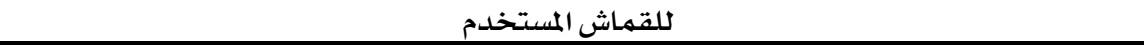 } \\
\hline الترتيب & |تقييم الجودة & زالامتصاص . & البياض \% & وزن المربع & نسبة استطالة & نسبة استطالة & قالحمة شد & | السداء \% & \\
\hline 4 & 414.17 & 2.22 & 29.07 & 81.87 & 81.82 & 54.55 & 84.85 & 79.80 & عينات التبييض بـ H2O2 \\
\hline 3 & 473.55 & 10.00 & 17.44 & 93.18 & 92.73 & 67.27 & 96.97 & 95.96 & عينات تركيز ب جم / لتر \\
\hline 2 & 477.91 & 14.29 & 30.23 & 92.79 & 90.91 & 61.82 & 94.95 & 92.93 & عينات تركيز هجم / لتر \\
\hline 1 & 491.33 & 25.00 & 47.67 & 92.40 & 87.27 & 58.18 & 91.92 & 88.89 & عينات تركيز V جم / لتز \\
\hline
\end{tabular}




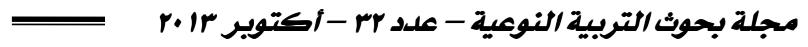

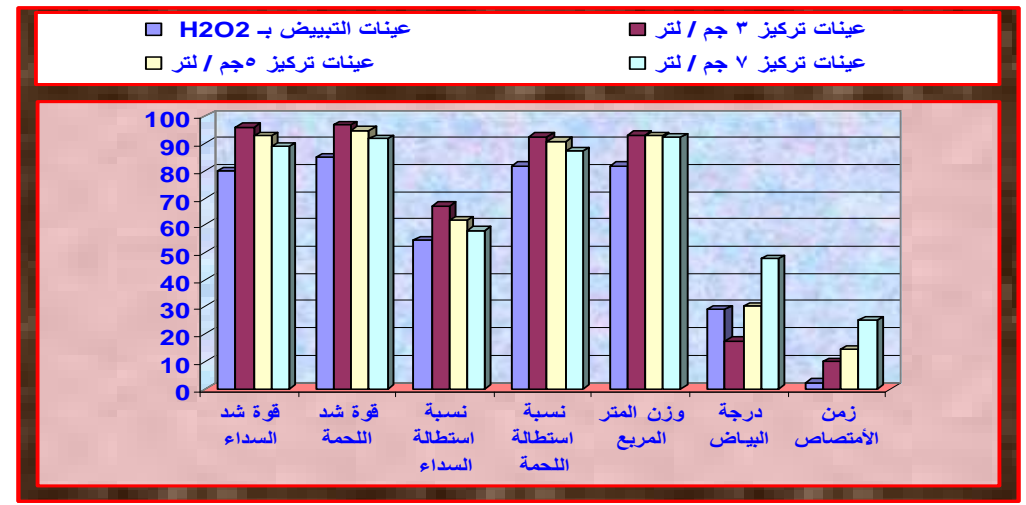

شكل (1) تأثير تركيز مادة بيريورات الصوديوم على خواص الأداء الوظيفي فى ضوء تقييم الجودة

\begin{tabular}{|c|c|}
\hline نسبة اسنطالة السداء 28.18 & نسبة استطالة السداء 24.55 \\
\hline شكل (r) أفضل العينات فى ضوء تقييم الجودة & 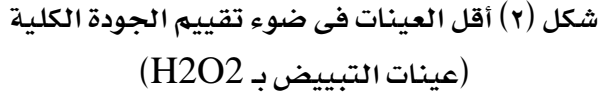 \\
\hline
\end{tabular}

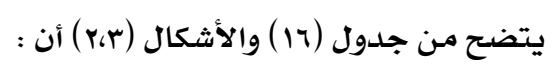

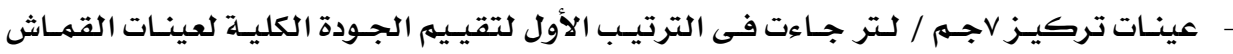

$$
\text { المستخدم تحت البحث . }
$$

- عينات التبييض بـ H2O2 جاءت فى الترتيب الرابع والأخير بالنسبة لتقييم الجودة الكلية . من كل ما سبق وبالرغم من أنه كلما زاد تركيز مـادة بيربورات الصوديوم كلهـا قلت قوة

الشد ،إلا أنه عند التبييض من ما سبق

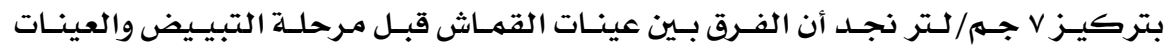

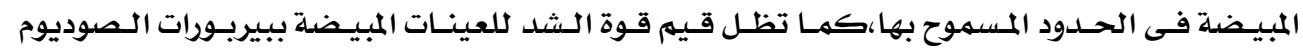

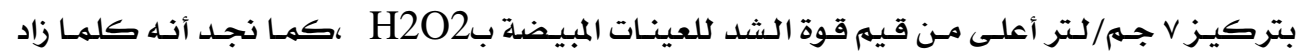

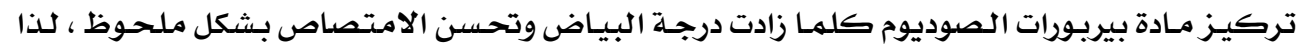

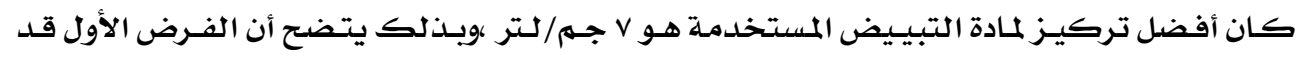


توجد فروق ذات دلالة إحصائية بين درجة حرارة عملية التبييض المستخدمة وخـواص الأداء

الوظيفي للقماش تحت البحث

• نتائج الخواص الطبيعية والميكانيكية لعينات القماش تحت البحث :

1-

أولا :قوة الشد فى اتجاه السداء :

جدول (IV)تحليل التباين لتأثيراختلاف درجة حرارةعملية التبييض المستخدمة

على قوة الشد في اتجاه السداء

\begin{tabular}{|c|c|c|c|c|c|}
\hline الدلالة & قيمة (ف) & درجات الحرية & متوسط المربعات & مجموع المربعات & سلداs \\
\hline \multirow{3}{*}{0.01 داJ } & \multirow{2}{*}{14.675} & 3 & 3549.000 & 10647.000 & بين المجموعات \\
\hline & & 8 & 241.833 & 1934.667 & داخل المجموعات \\
\hline & & 11 & & 12581.667 & جموع \\
\hline
\end{tabular}

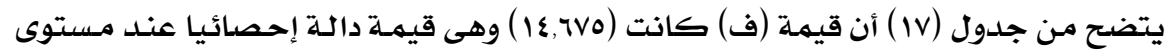

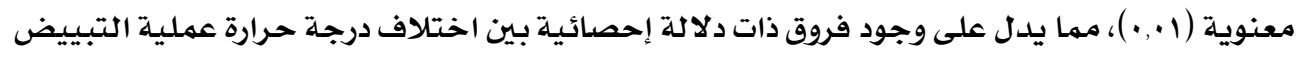

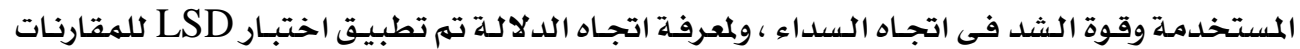

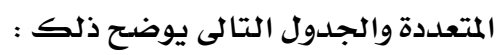

جدول(1) اختبارLSD للمقارنات المتعددة لتأثيراختلاف درجة حرارة عملية التبييض المستخدمة على قوة الشد في اتجاه السداء

\begin{tabular}{|c|c|c|c|c|}
\hline 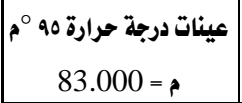 & 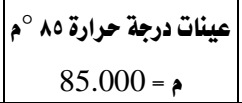 & 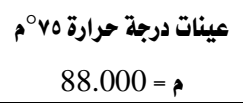 & عينات التبييض بـ & سلاء \\
\hline & & & & عينات التبييض بـ H2O2 \\
\hline & & & $\pm * 9.000$ & عينات درجة حرارة vo م م \\
\hline & & $\times * 3.000$ & $\pm * 6.000$ & عينات درجة حرارة ه1 م م \\
\hline & $\neq 2.000$ & $* * 5.000$ & $* * 4.000$ & عينات درجة حرارة 90 م \\
\hline
\end{tabular}

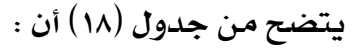

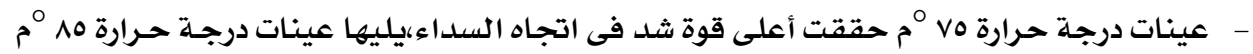

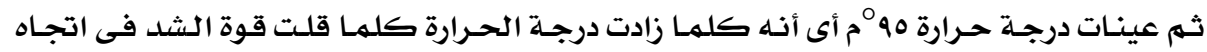

$$
\text { السداء. }
$$

- عينات التبييض بH2O2 أعطت أقل قوة شد فى اتجاه السداء . 


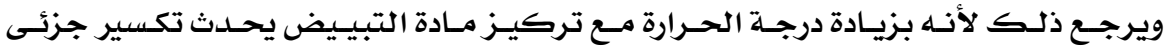

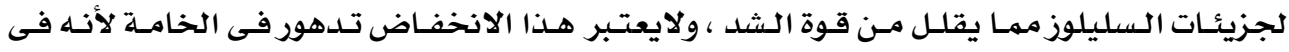

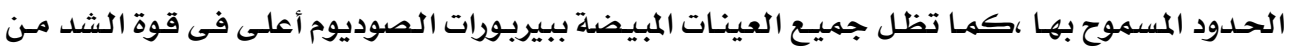

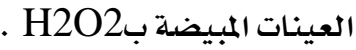
ثانيا : قوة الشد فى اتجاه اللحمـة : جدول (19) تحليل التباين لتأثيراختلاف درجة حرارةعملية التبييض المستخدمـة على قوة الشل في اتجـاه اللحمهة

\begin{tabular}{|c|c|c|c|c|c|}
\hline الدلالة & قيمة (ف) & درجات الحرية & متوسط المربعات & مجموع المربعات & لحمة \\
\hline \multirow{3}{*}{0.01 دال } & \multirow{2}{*}{18.074} & 3 & 3864.750 & 11594.250 & بين المجموعات \\
\hline & & 8 & 213.833 & 1710.667 & داخل المجموعات \\
\hline & & 11 & & 13304.917 & المجموع \\
\hline
\end{tabular}

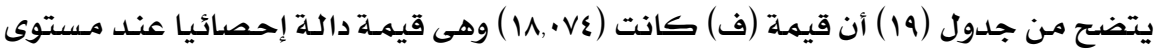

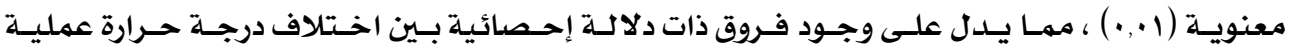

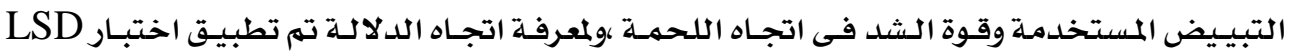

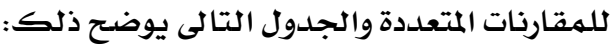

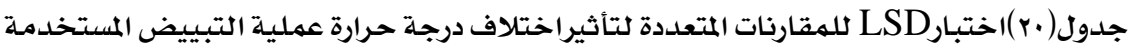
على قوة الشد فى اتجـاه اللحمهـة

\begin{tabular}{|c|c|c|c|c|}
\hline 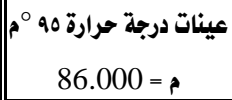 & 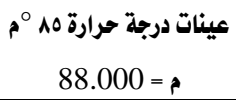 & 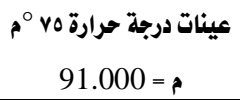 & 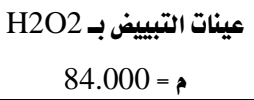 & لحمة \\
\hline & & & & عينات التبييض بـ H2O2 \\
\hline & & & $\pm x+7.000$ & عينات درجة حرارة V م م \\
\hline & & \pm \pm 3.000 & $\pm x+000$ & عينات درجة حرارة ه^ م \\
\hline & \pm 2.000 & $\pm \neq 5.000$ & \pm 2.000 & عينات درجة حرارة هو ○م \\
\hline
\end{tabular}

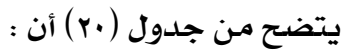

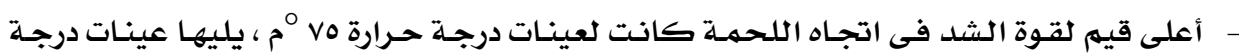

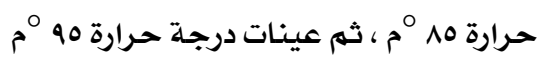

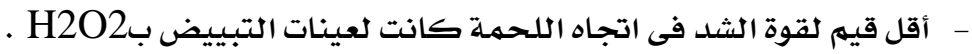


جدول ( ا r ) تحليل التباين لتأثيراختاف درجـة حرارةعملية التبييض المستخدمة على نسبة الاستطالة

\begin{tabular}{|c|c|c|c|c|c|}
\hline \multicolumn{6}{|c|}{ في اتجـاه السلداء } \\
\hline الدلالة & قيمة (ف) & درجات الحرية & متوسط المربعات & مجموع المربعات & سلداs \\
\hline \multirow{3}{*}{0.01 دال } & \multirow{2}{*}{7.418} & 3 & 100.318 & 300.954 & بين المجموعات \\
\hline & & 8 & 13.523 & 108.187 & داخل المججموعات \\
\hline & & 11 & & 409.141 & المجموع \\
\hline
\end{tabular}

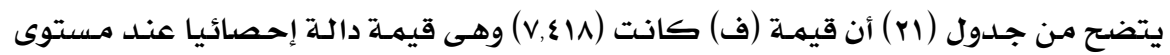

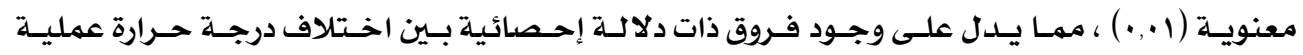

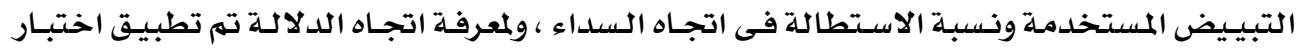

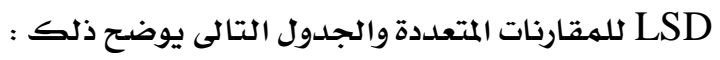

جلدول (Y ) ) اختبار LSD للمقارنات المتعددة لتأثير اختالاف درجـة حرارة عملية التبييض المستخدمـة على نسبـة الاستطالة في اتجـاه السلداء

\begin{tabular}{|c|c|c|c|c|}
\hline 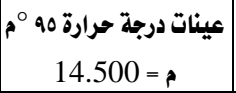 & 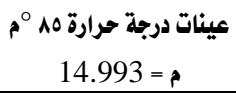 & 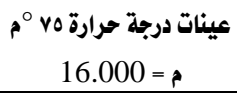 & 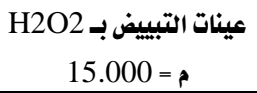 & 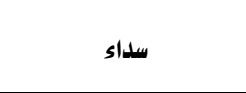 \\
\hline & & & & عينات التبييض بـ H2O2 \\
\hline & & & $* 1.000$ & عينات درجة حرارة vo م \\
\hline & & $* 1.006$ & -0.006 & عينات درجة حرارة ^ ^م م \\
\hline & $* 0.493$ & $* * 1.500$ & $* 0.500$ & عينات درجة حرارة ه9 ○م \\
\hline
\end{tabular}

$$
\text { يتضح من جدول (rr) أن : }
$$

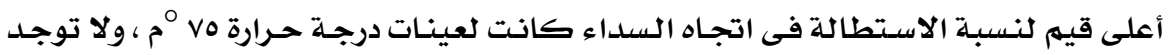

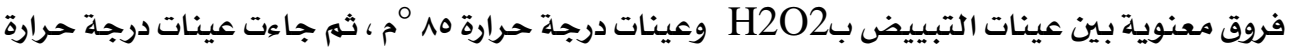

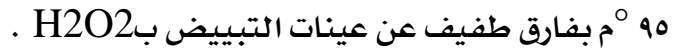
ثانيا :نسبـة الاستطانة فى اتجاه اللحمهة : جلدول ( س ) تحليل التباين لتأثيراختلاف درجة حرارة عملية التبييض المستخلدمة على نسبـة الاستطالة فى

\begin{tabular}{|c|c|c|c|c|c|}
\hline الدلالة & قيمة (ف) & درجات الحرية & متوسط المربعات & مجموع المربعات & لحمة \\
\hline \multirow{3}{*}{0.0101 داJ } & \multirow{2}{*}{6.227} & 3 & 218.864 & 656.593 & بين المجهوعات \\
\hline & & 8 & 35.146 & 281.167 & داخل المججموعات \\
\hline & & 11 & & 937.760 & المجموع \\
\hline
\end{tabular}
اتجاه اللحممة 


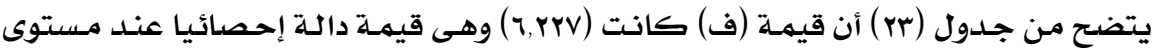

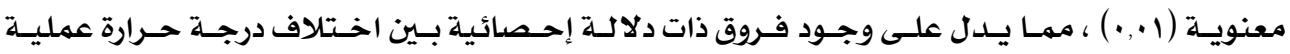

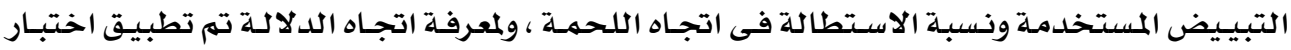

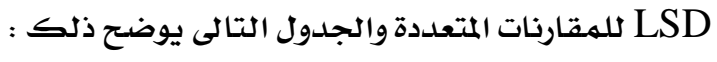
جدول (๕) اختبارLSD للمقارنات المتعددة لتأثيراختلاف درجة حرارةعملية التبييض المستخدمـة على نسبة الاستطالة في اتجاه اللحمة

\begin{tabular}{|c|c|c|c|c|}
\hline 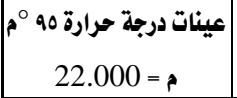 & عينات درجة حرارة 10 م $22.492=0$ & 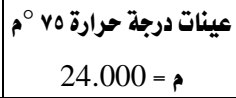 & عينات التبييض بـ $22.500=$ م2 & لجمة \\
\hline & & & & عينات التبييض بـ H2O2 \\
\hline & & & $* * 1.500$ & عينات درجة حرارة Vo م \\
\hline & & $* * 1.508$ & -0.008 & عينات درجة حرارة 10 م \\
\hline & $* 0.492$ & $* * 2.000$ & $* 0.500$ & عينات درجة حرارة 90 × \\
\hline
\end{tabular}

$$
\text { يتضح من جدول (؟) أن: }
$$

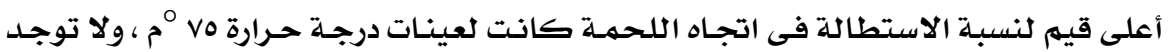

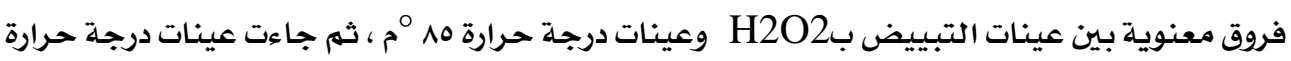
.

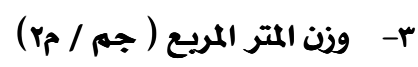
جدول (0ب) تحليل التباين لتأثيراختالاف درجة حرارة عملية التبييض المستخدمـة على وزن المتر المربع

\begin{tabular}{|c|c|c|c|c|c|}
\hline الدلالة & قيمة (ف) & درجات الحرية & متوسط المربعات & مجموع المربعات & وزن المتر المربع \\
\hline \multirow[t]{3}{*}{0.0101 دال } & \multirow{2}{*}{22.232} & 3 & 218.617 & 655.850 & بين المجموعات \\
\hline & & 8 & 9.833 & 78.667 & داخل المجموعات \\
\hline & & 11 & & 734.517 & المجموع \\
\hline
\end{tabular}

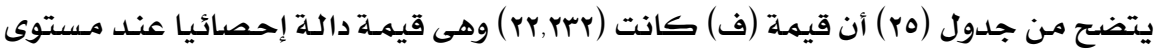

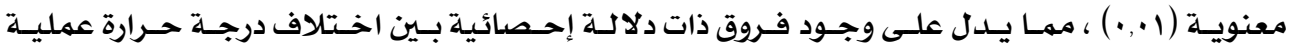

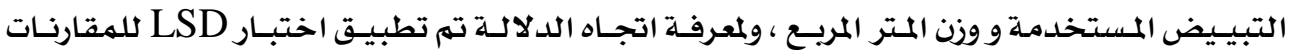

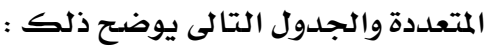


جدول (جr) اختبار LSD للمقارنات المتعددة لتأثيراختلاف درجة حرارة عملية التبييض المستخدمة على وزن المتر المربع م

\begin{tabular}{|c|c|c|c|c|}
\hline 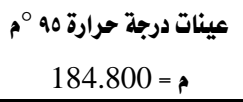 & 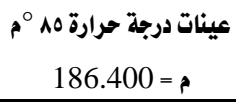 & 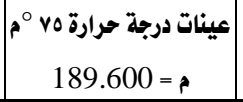 & 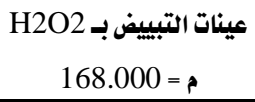 & وزن المتر المربع \\
\hline & & & & مينات التبييض بـ H2O2 \\
\hline & & & $* * 21.600$ & عينات درجة حرارة vo م م \\
\hline & & $* * 3.200$ & $* * 18.400$ & عينات درجة حرارة ه1 م م \\
\hline & $* 1.600$ & $* * 4.800$ & $* * 16.800$ & عينات درجة حرارة 90 م م \\
\hline
\end{tabular}

يتضح من جدول (צr) أن :

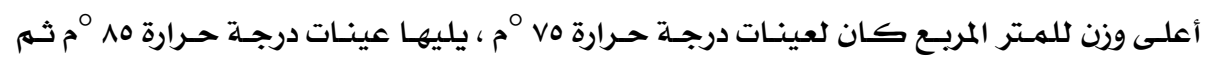

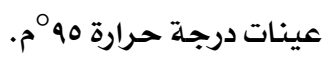

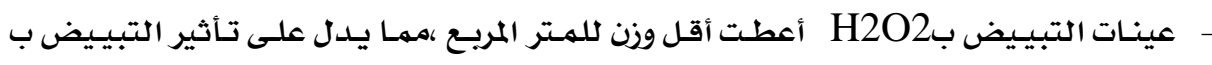

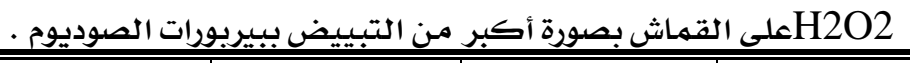

\begin{tabular}{|c|c|c|c|c|}
\hline 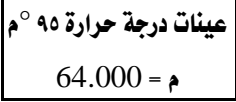 & 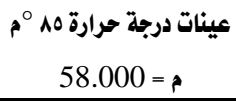 & 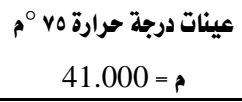 & 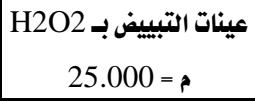 & درجة البياض \\
\hline & & & & عينات التبييض بـ H2O2 \\
\hline & & & $* * 16.000$ & عينات درجة حرارة vo م \\
\hline & & $* * 17.000$ & $* * 33.000$ & عينات درجة حرارة ه م م \\
\hline & $* * 6.000$ & $* * 23.000$ & $* * 39.000$ & عينات درجة حرارة ه9 م م \\
\hline
\end{tabular}

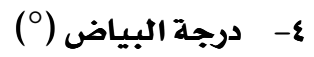
جدول ( ) ) تحليل التباين لتأثيراختلاف درجة حرارة عملية التبييض المستخدمة على درجة البياض

\begin{tabular}{|c|c|c|c|c|c|}
\hline الدلالة & قيمة (ف) & درجات الحرية & متوسط المربعات & مجموع المربعات & درجة البياض \\
\hline \multirow{3}{*}{0.01 دار } & \multirow{2}{*}{24.372} & 3 & 703.568 & 2110.703 & بين المجموعات \\
\hline & & 8 & 28.867 & 230.940 & داخل المجموعات \\
\hline & & 11 & & 2341.643 & المجموع \\
\hline
\end{tabular}

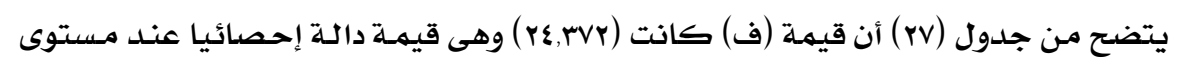

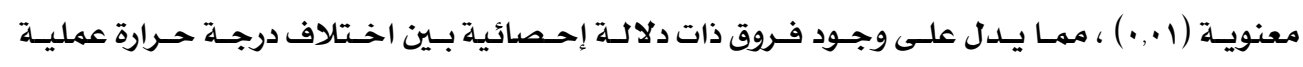

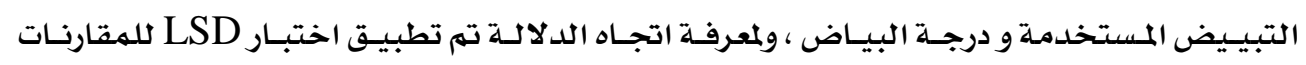

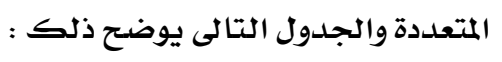


جدول ( ) اختبار LSD للمقارنات المتعددة لتأثيراختاف درجة حرارة عملية التبييض المستخدمة على درجة

\begin{tabular}{|c|c|c|c|c|}
\hline 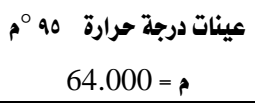 & 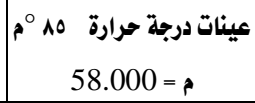 & 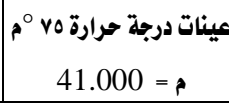 & 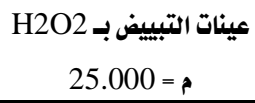 & درجة البياض \\
\hline & & & & عينات التبييض بـ H2O2 \\
\hline & & & $* * 16.000$ & عينات درجة حرارة v مo م \\
\hline & & $* * 17.000$ & $* * 33.000$ & عينات درجة حرارة ه م م \\
\hline & $* * 6.000$ & $* * 23.000$ & $* * 39.000$ & عينات درجة حرارة ه9 م \\
\hline
\end{tabular}

يتضح من جدول (rی) أن:

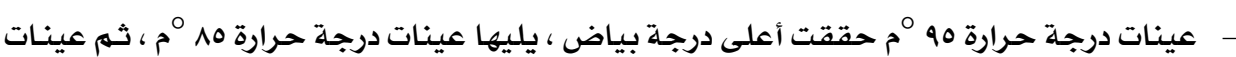

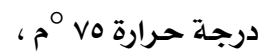

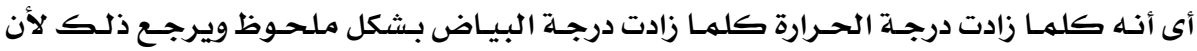

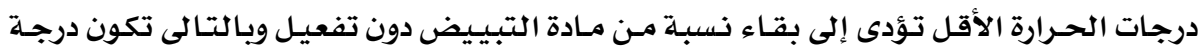

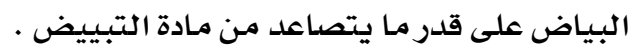

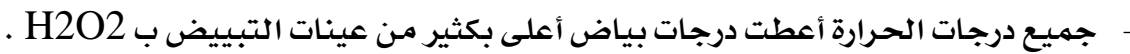

ه- - زمن الامتصاص (ثانية)

جدول ( و ) ) تحليل التباين لتأثيراختالاف درجـة حرارة عملية التبييض المستخدمـة على زمن الامتصاص

\begin{tabular}{|c|c|c|c|c|c|}
\hline اللدلالة & قيمة (ف) & درجات الحرية & متوسط المربعات & مجموع المربعات & الامتصاص \\
\hline \multirow{3}{*}{0.01 دال } & \multirow{2}{*}{27.084} & 3 & 943.641 & 2830.922 & بين المجموعات \\
\hline & & 8 & 34.841 & 278.727 & داخل المجموعات \\
\hline & & 11 & & 3109.649 & المجموع \\
\hline
\end{tabular}

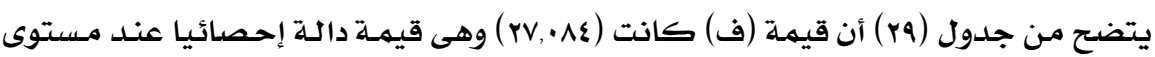

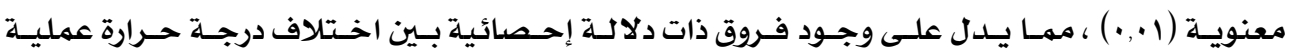

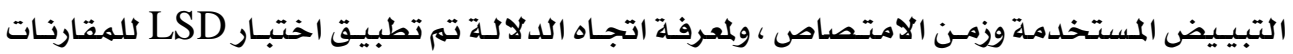

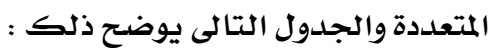


جدول (•r) اختبار LSD للمقارنات المتعددة لتأثير اختلاف درجة حرارة عملية التبييض المستخدمة على زمن الامتصاص

\begin{tabular}{|c|c|c|c|c|}
\hline 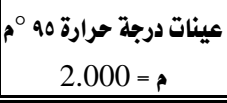 & 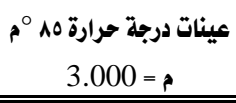 & 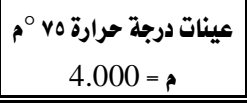 & 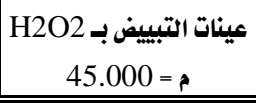 & الامتصاص \\
\hline \multirow{4}{*}{$2.000=$} & & & & عينات التبييض بـ H2O2 \\
\hline & & & $* * 41.000$ & عينات درجة حرارة vo م \\
\hline & & $* 1.000$ & $* * 42.000$ & عينات درجة حرارة 10 ×م \\
\hline & $* 1.000$ & $* 2.000$ & $* * 43.000$ & عينات درجة حرارة ه9 ○م \\
\hline
\end{tabular}

يتضح من جدول (•r) أن :

- أطول زمـن امتصاص كان لعينات التبييض ب H2O2بشكل واضع ، يليها عينـات درجـة حـرارة

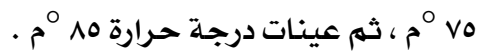

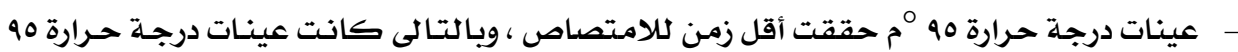
م هى الأفضل حيث أنه كلما قل زمن الامتصاص كله كلما كان الامتصاص أفضل . ويعتبر الامتصساص فى حالة التبيـيض ببيربـورات الصوديوم نتيجـة مهتـازة وغير متوقعسة لعـدم وجود صودا كاوية أو مادة ابتلال أثناء التبييض بهذه المادة .

• تقيـيم الجـودة لتـأثير درجـة حـرارة عمليـة التبيـيض على خـواص الأداء الـوظيفى نلقمـاث تحست البـحث:

جدول رقم ( اس) تقييم الجودة لتأثير اختالاف درجة حرارة عملية التبييض على خواص الأداء الوظيفي للقماش المستخدم

\begin{tabular}{|c|c|c|c|c|c|c|c|c|c|}
\hline الترتيب & تقتييم الجودة & $\begin{array}{c}\text { زمن } \\
\text { الامتصاص \% } \\
\end{array}$ & |لبياض \% & وزن الماتر & نسبة استطالة & نسبة استطالة & قالمة شد اللحمة & قوة شد & \\
\hline 4 & 414.17 & 2.22 & 29.07 & 81.87 & 81.82 & 54.55 & 84.85 & 79.80 & مينات التبييض بـ H2O2 \\
\hline 3 & 491.33 & 25.00 & 47.67 & 92.40 & 87.27 & 58.18 & 91.92 & 88.89 & عينات درجة حرارة (75)م \\
\hline 2 & 502.67 & 33.33 & 67.44 & 90.84 & 81.79 & 54.52 & 88.89 & 85.86 & عينات درجة حرارة (85)م \\
\hline 1 & 517.91 & 50.00 & 74.42 & 90.06 & 80.00 & 52.73 & 86.87 & 83.84 & عينات درجة حرارة (95)م \\
\hline
\end{tabular}

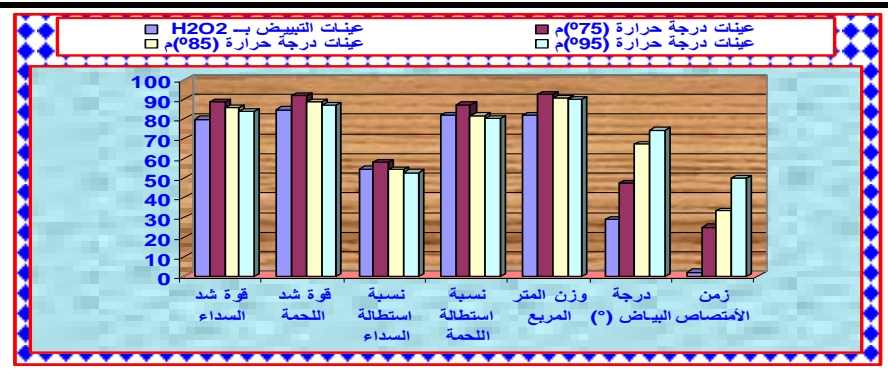

شكل (ع) تأثير درجة حرارة عملية التبييض على خواص الأداء الوظيفي فى ضوء تقييم الجودة 


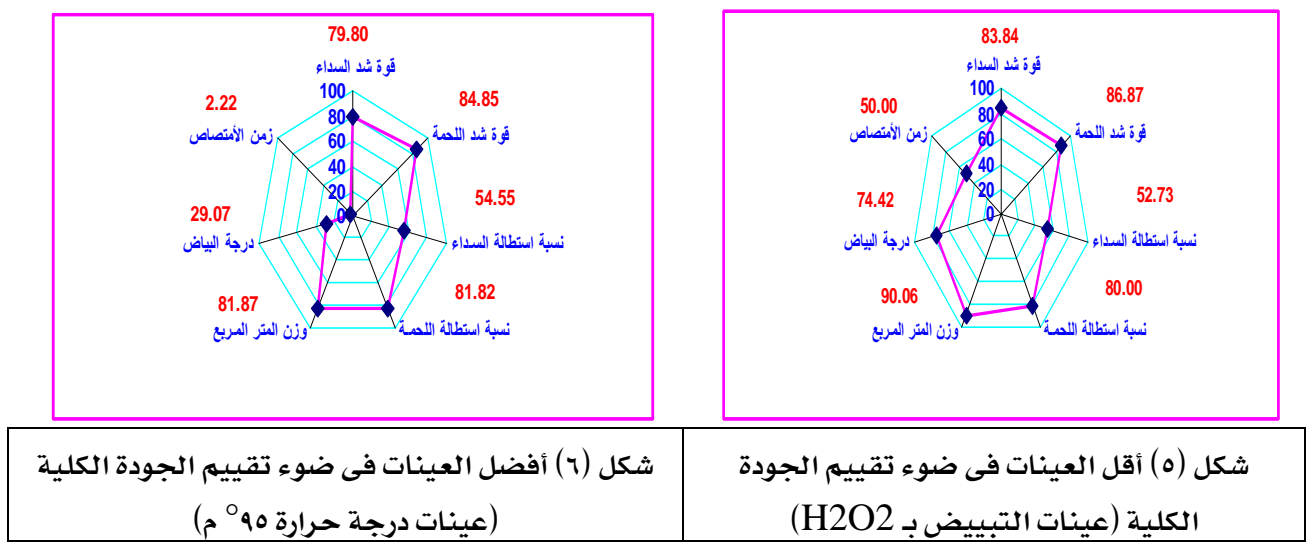

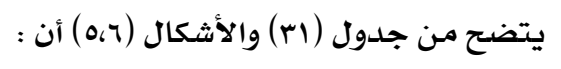

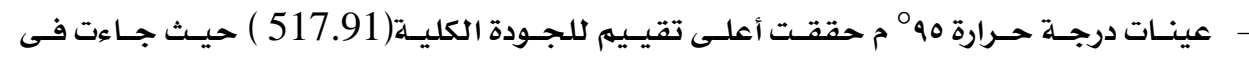

$$
\text { الترتيب الأول . }
$$

عينات التبييض بـ H2O2 جـاءت في الترتيـب الأخير بـين العينـات وأعطت أقل تقييم للجـودة

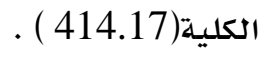

من كل ما سبق نجد أن عينات درجة حرارة ه ه م حققت أعلى درجة بياض وأعلى امتصاص

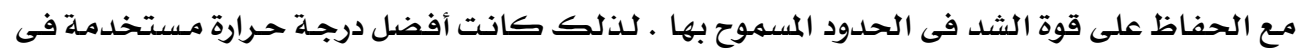

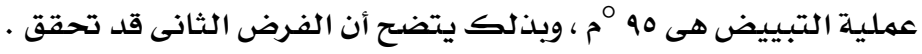
الفرض الثالث : معلئ التيديف

توجد فروق ذات دلالة إحصائية بين زمن عملية التبييض المستخدم وخـواص الأداء الوظيفي

$$
\text { للقماش تحت البحث }
$$

\begin{tabular}{|c|c|c|c|c|c|}
\hline الدلالة & قيمة (ف) & درجات الحرية & متوسط المربعات & مجموع المربعات & سلداء \\
\hline \multirow{3}{*}{0.01 دال } & \multirow{2}{*}{11.580} & 3 & 2975.120 & 8925.360 & بين المجموعات \\
\hline & & 8 & 256.920 & 2055.360 & داخل المجموعات \\
\hline & & 11 & & 10980.720 & المجموع \\
\hline
\end{tabular}

• نتائج الخواص الطبيعية والميكانيكية لعينات القماش تحت البحث :

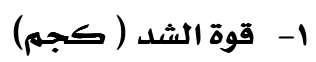

أولا : قوة الشد فى اتجاه السداء :

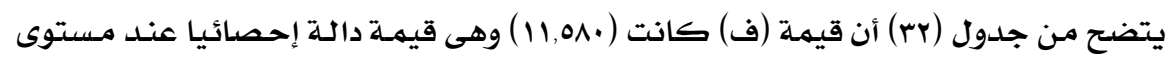

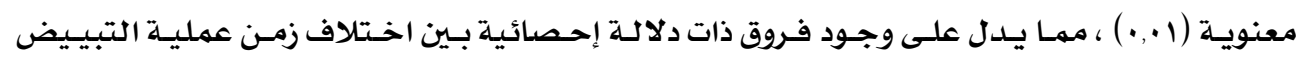




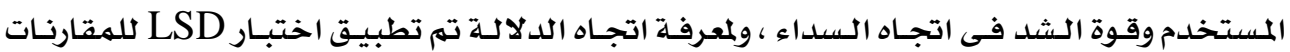

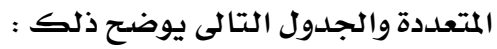

جدول (r) اختبارLSDD للمقارنات المتعددة لتأثير اختلاف زمن عملية التبييض المستخدم على قوة الشد في اتجـاه السداء

\begin{tabular}{|c|c|c|c|c|}
\hline 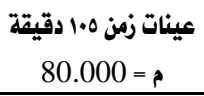 & 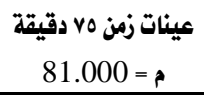 & عينات زمن 0؟ دقيقة & 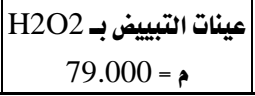 & سلاء \\
\hline & & & & عينات التبييض بـ H2O2 \\
\hline & & & $* * 4.000$ & عينات زمن هـ دقيقة \\
\hline & & $* 2.000$ & $* 2.000$ & عينات زمن vo دقيقة \\
\hline & -1.000 & $* * 3.000$ & -1.000 & عينات زمن 1 ادقيقة \\
\hline
\end{tabular}

يتضح من جدول (rr) أن :

- أعلى قيم لقوة الشد فى اتجاه السداء كانت لعينات زمن ه؛ دقيقة يليها عينات زمن و V دقيقة.

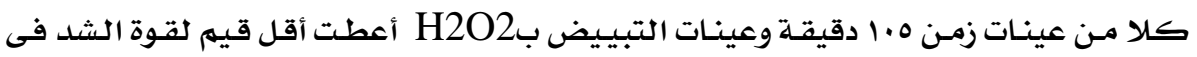

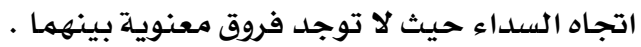
ثانيا : قوة الشد فى اتجاه اللحمـة :

جدول ( ع ) تحليل التباين لتأثير اختلاف زمن عملية التبييض المستخدم على قوة الشد في اتجاه اللحمة

\begin{tabular}{|c|c|c|c|c|c|}
\hline الدلالة & قيمة (ف) & درجات الحرية & متوسط المربعات & مجموع المربعات & لحمة \\
\hline \multirow{3}{*}{0.01 دال } & \multirow{2}{*}{14.490} & 3 & 3339.337 & 10018.010 & بين المجموعات \\
\hline & & 8 & 230.453 & 1843.627 & داخل المجموعات \\
\hline & & 11 & & 11861.637 & المجموع \\
\hline
\end{tabular}

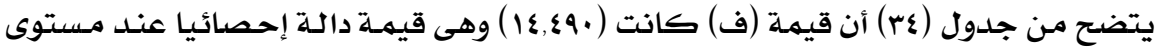

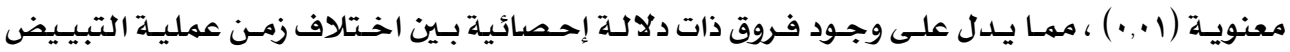

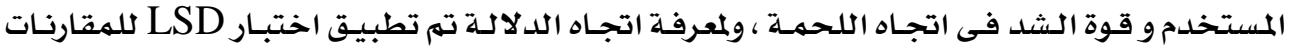

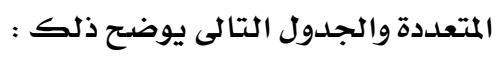

جدول ( ه ) اختبار LSD للمقارنات المتعددة لتأثير اختلاف زمن عملية التبييض المستخدم على قوة الشلد في اتجاه انللحمهة

\begin{tabular}{|c|c|c|c|c|}
\hline 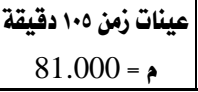 & 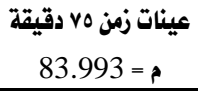 & 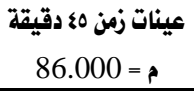 & عينات التبييض بـ & ل لحمة \\
\hline & & & & عينات التبييض بـ H2O2 \\
\hline & & & $* 2.000$ & عينات زمن 0؛ دقيقة \\
\hline & & $* 2.006$ & -0.007 & عينات زمن v دقيقة \\
\hline & $* * 2.993$ & $* * 5.000$ & $* * 3.000$ & عينات زمن 0.ا دقيقة \\
\hline
\end{tabular}




$$
\text { يتضح من جدول (ro) أن : }
$$

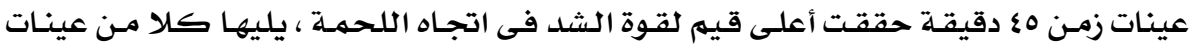

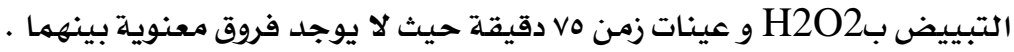

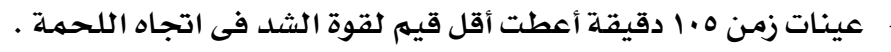

r- نسبة الاستطالة

أولا :نسبة الاستطالة فى اتجاه السداء :

جدول (جr) تحليل التباين لتأثير اختلاف زمن عملية التبييض المستخدم

\begin{tabular}{|c|c|c|c|c|c|}
\hline الدلالة & قيمة (ف) & درجات الحرية & متوسط المربعات & مجموع المربعات & سلاء \\
\hline \multirow{3}{*}{0.01 دال } & \multirow{2}{*}{6.613} & 3 & 82.798 & 248.395 & بين المجموعات \\
\hline & & 8 & 12.521 & 100.167 & داخل المجموعات \\
\hline & & 11 & & 348.562 & المجموع \\
\hline
\end{tabular}

على نسبـة الاستطالة في اتجاه السداء

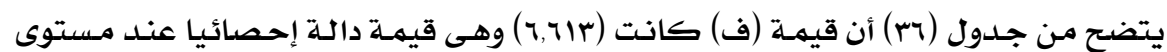

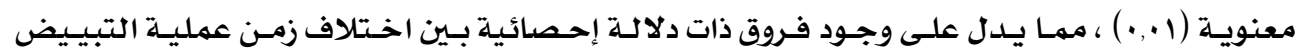

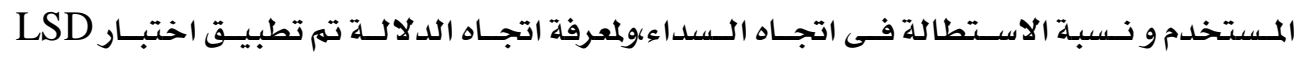

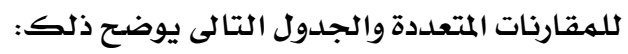
جدول (rv) اختبار LSD للمقارنات المتعددة لتأثير اختلاف زمن عملية التبييض المستخدم

\begin{tabular}{|c|c|c|c|c|}
\hline عينات زمن 1 ادقيقة & 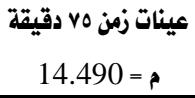 & عينات زمن 0؛ دقيقة & 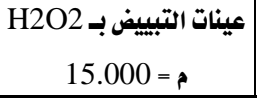 & 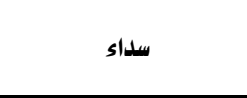 \\
\hline & & & & عينات التبييض بـ H2O2 \\
\hline & & & $* 0.500$ & عينات زمن 0؛ دقيقة \\
\hline & & -0.010 & $* 0.510$ & عينات زمن vo دقيقة \\
\hline & $* 0.490$ & $* 0.500$ & $* 1.000$ & عينات زمن 1 درقيقة \\
\hline
\end{tabular}
على نسبة الاستطالة في اتجاه السداء

يتضح من جدول (rv) أن :

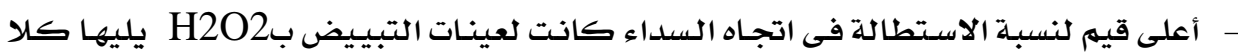

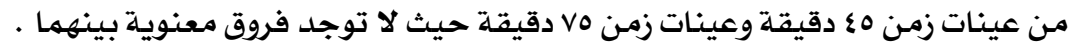

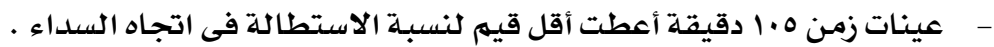


ثانيا : نسبة الاستطالة فى اتجاه اللحمـة :

جدول (r^) تحليل التباين لتأثير اختلاف زمن عملية التبييض المستخدم على نسبة الاستطالة في اتجاه اللحمهة

\begin{tabular}{|c|c|c|c|c|c|}
\hline الدلالة & قيمة (ف) & درجات الحرية & متوسط المربعات & مجموع المربعات & لحمة \\
\hline \multirow{3}{*}{0.01 دال } & \multirow{2}{*}{6.840} & 3 & 185.250 & 555.750 & بين المجموعات \\
\hline & & 8 & 27.083 & 216.667 & داخل المجموعات \\
\hline & & 11 & & 772.417 & المجموع \\
\hline
\end{tabular}

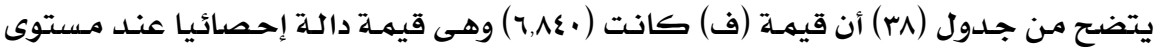

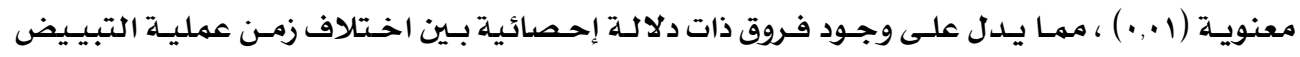

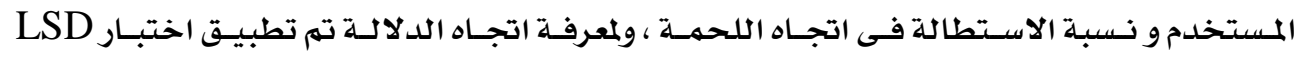

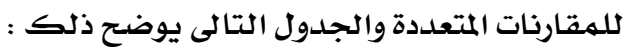
جدول (rq) اختبار LSD للمقارنات المتعددة لتأثير اختلاف زمن عملية التبييض المستخدم على نسبة

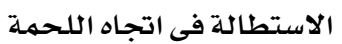

\begin{tabular}{|c|c|c|c|c|}
\hline عينات زمن 1.0 & عينات زمن vo دقيقة & عينات زمن 0؟ دقيقة & 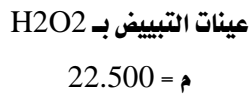 & لحمة \\
\hline & & & & عينات التبييض بـ H2O2 \\
\hline & & & $* 0.500$ & عينات زمن ه؟ دقيقة \\
\hline & & $* 0.500$ & $* 1.000$ & عينات زمن vo دقيقة \\
\hline & $* 1.000$ & $* * 1.500$ & $* * 2.000$ & عينات زمن 0. 1 دقيقة \\
\hline
\end{tabular}

يتضح من جدول (rq) أن :

عينات التبييض بH2O2 حققت أعلى قيم لنسبـة الاستطالتة فى اتجـاه اللحمـة يليهاعينـات زمن 0؛ دقيقة ثم عينات زمن V0 دقيقة.

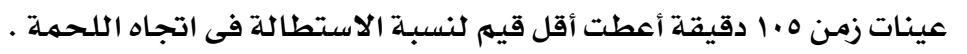

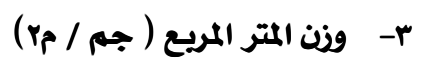

جدول ( •ـ ) تحليل التباين لتأثير اختلاف زمن عملية التبييض المستخلدم على وزن المتر المربع

\begin{tabular}{|c|c|c|c|c|c|}
\hline الدلالة & قيمة (ف) & درجات الحرية & متوسط المربعات & مجموع المربعات & وزن المتر المربع \\
\hline \multirow{3}{*}{0.01 دال } & \multirow{2}{*}{8.167} & 3 & 13826.080 & 41478.240 & بين المجموعات \\
\hline & & 8 & 1692.833 & 13542.667 & داخل المجموعات \\
\hline & & 11 & & 55020.907 & المجموع \\
\hline
\end{tabular}




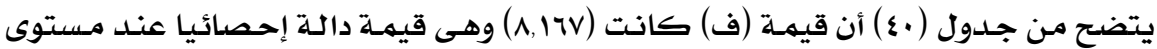

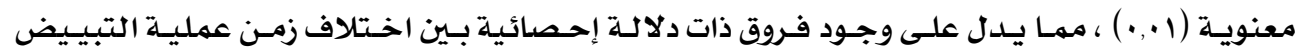

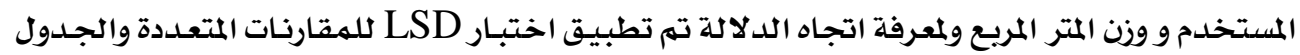

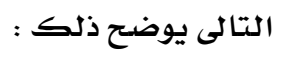

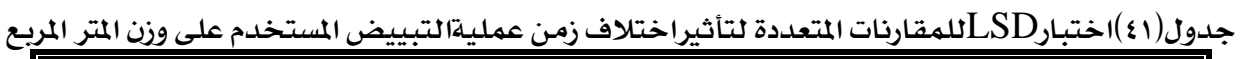

\begin{tabular}{|c|c|c|c|c|}
\hline عينات زمز 1.00 دقيقة & عينات زمن vo دقيقة & عينات زمن 1 ـ دقيقة 184.800 & | عينات التبييض بـ 168.000 = 168. & وزن المتز المربع \\
\hline & & & & عينات التبييض بـ H2O2 \\
\hline & & & $* * 16.800$ & عينات زمن هـ دقيقة \\
\hline & & -1.200 & $* * 15.600$ & عينات زمن vo دقيقة \\
\hline & $* 2.800$ & $* * 4.000$ & $* * 12.800$ & عينات زمز 1.1 دقيقة \\
\hline
\end{tabular}

يتضح من جدول (1ء) أن :

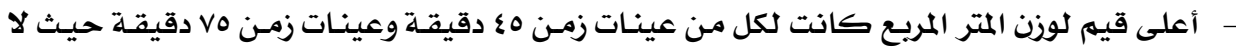

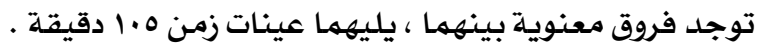

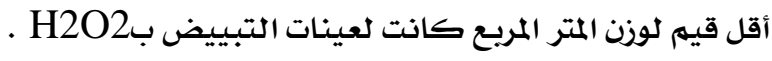

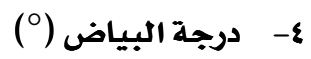

جدول (rع) تحليل التباين لتأثير اختلاف زمن عملية التبييض المستخدم على درجة البياض

\begin{tabular}{|c|c|c|c|c|c|}
\hline الدلالة & قيهة (ف) & درجات الحرية & متوسط المربعات & مجموع المربعات & درجة البياض \\
\hline \multirow{3}{*}{0.01 دال } & \multirow{2}{*}{31.775} & 3 & 1694.667 & 5084.000 & بين المجموعات \\
\hline & & 8 & 53.333 & 426.667 & داخل المجموعات \\
\hline & & 11 & & 5510.667 & المجموع \\
\hline
\end{tabular}

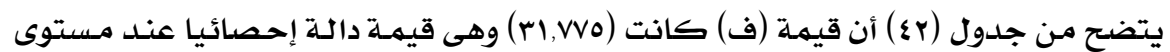

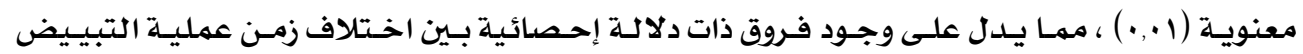

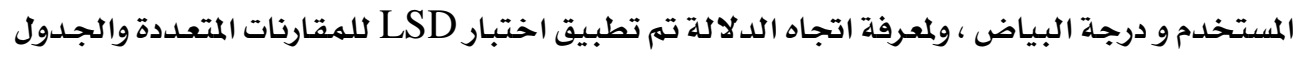

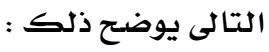

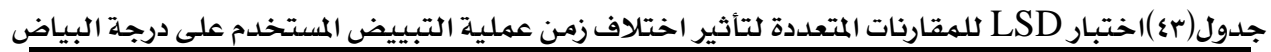

\begin{tabular}{|c|c|c|c|c|}
\hline عينات زمن 1.0 دقيقة & 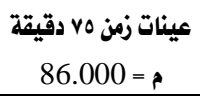 & عينات زمن 0ء دقيقة & 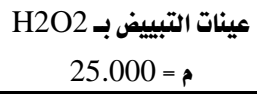 & درجة البياض \\
\hline & & & & عينات التبييض بـ H2O2 \\
\hline & & & $* * 39.000$ & عينات زمن هـ دقيقة \\
\hline & & $* * 22.000$ & $* * 61.000$ & عينات زمن \ه دقيقة \\
\hline & $* * 10.000$ & $* * 12.000$ & $* * 51.000$ & عينات زمن 1 دقيقة \\
\hline
\end{tabular}




$$
\text { يتضح من جدول (r) أن : }
$$

زمـن V0 دقيقة حقق أعلى قيم لدرجـة البيـاض يليـه عينـات زمـن هـ ـ 1 دقيقـة ثم عينـات زمـن ه؛

$$
\text { دقيقة . زمن }
$$

$$
\text { عينات التبييض بH2O2 دأعطت أقل قيم لدرجة البياض . }
$$

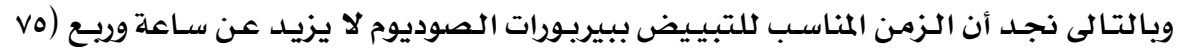

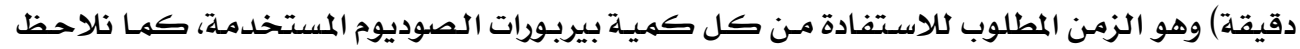

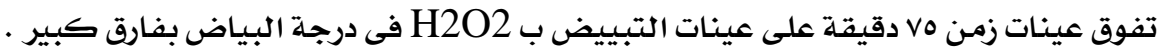

\begin{tabular}{|c|c|c|c|c|c|}
\hline الدلالة & قيمة (ف) & درجات الحرية & متوسط المربعات & مجموع المربعات & الامتصاص \\
\hline \multirow{3}{*}{0.01 داJ } & \multirow{2}{*}{24.116} & 3 & 972.667 & 2918.000 & بين المجموعات \\
\hline & & 8 & 40.333 & 322.667 & داخل المجموعات \\
\hline & & 11 & & 3240.667 & المجموع \\
\hline
\end{tabular}
ه - زمن الامتصاص ( ثانية)

جدول ( ؟ء ) تحليل التباين لتأثير اختالاف زمن عملية التبييض المستخدم على زمن الامتصاص

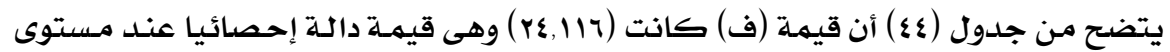

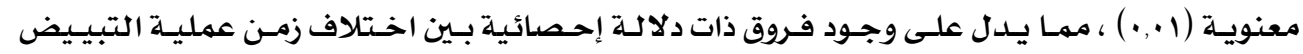

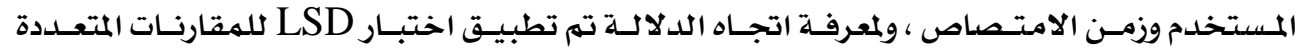

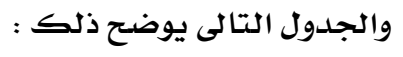

جدول (0؟) اختبار LSD للهقارنات المتعددة لتأثير اختلاف زمن عملية التبييض المستخدم

\begin{tabular}{||c|c|c|c|c||}
\hline عينات \\
\hline \\
\hline
\end{tabular}

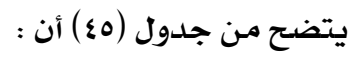

أعلى زمن امتصاص كان لعينات التبييض ب H2O2 بفارق كبير عن بـاقى العينات يليها

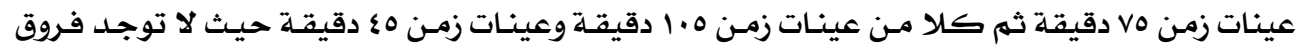

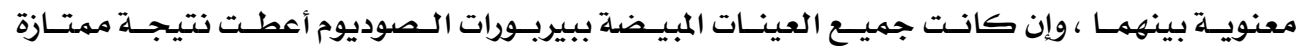
كلامتصاص وفى الحدود المقبولة لذلك . 


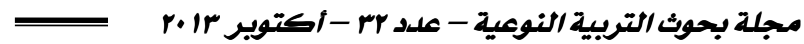

• تقييم الجودة لتأثير زمن عملية التبييض على خواص الأداء الوظيفى للقماش تحت البحث :

\begin{tabular}{|c|c|c|c|c|c|c|c|c|c|}
\hline | الترتيب| - التيب & تقيييم الجودة & | الامتصاص \% & | البياض \% & المرن المتر & |نسبة استطالة & نسبة استطالة & قالحمة شة & قوة شد & \\
\hline 4 & 414.17 & 2.22 & 29.07 & 81.87 & 81.82 & 54.55 & 84.85 & 79.80 & عينات التبييض بـ H2O2 \\
\hline 2 & 518.01 & 50.10 & 74.42 & 90.06 & 80.00 & 52.73 & 86.87 & 83.84 & عينات زمز 0ـ دقيقة \\
\hline 1 & 520.34 & 33.33 & 100.00 & 89.47 & 78.18 & 52.69 & 84.84 & 81.82 & عينات زمن vo دقيقة \\
\hline 3 & 514.56 & 50.00 & 88.37 & 88.11 & 74.55 & 50.91 & 81.82 & 80.81 & عينات زمن 0.1 دقيقة \\
\hline
\end{tabular}

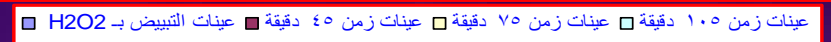

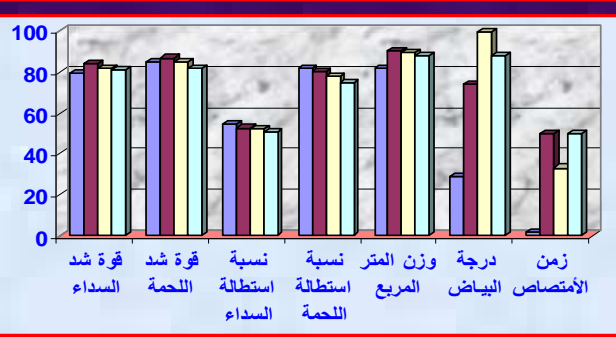

شكل (v) تأثير زمن التبييض على خواص الأداء الوظيفي فى ضوء تقييم الجودة

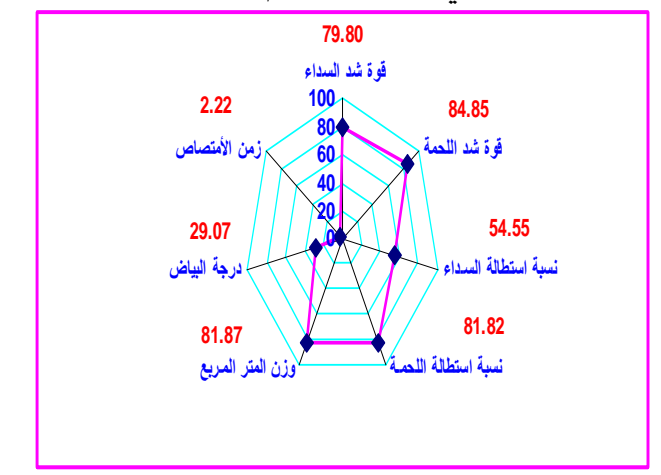

شكل (q) أفضل العينات فى ضوء تقييم الجودة الكلية

(عينات زمن V0 دقيقة)

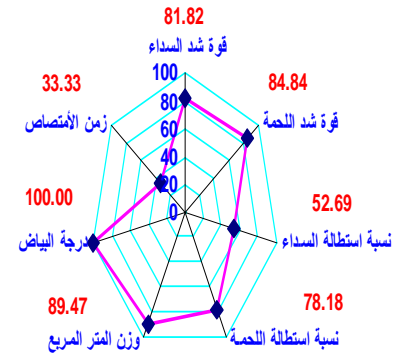

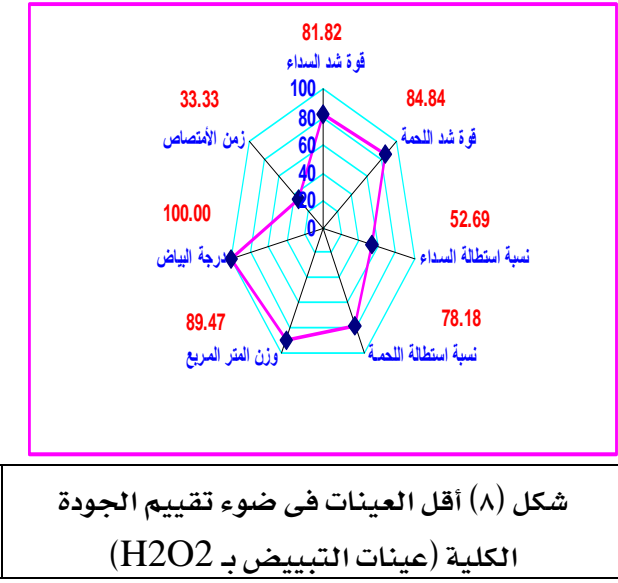

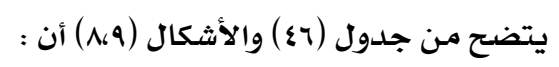

- أعلى تقييم للجودة الكلية هو (520.34) وذلك عند استخدام زمن V0 دقيقة .

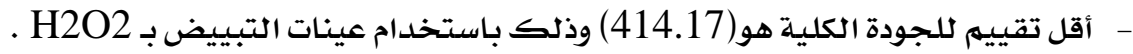




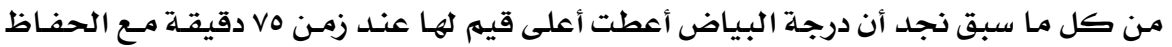

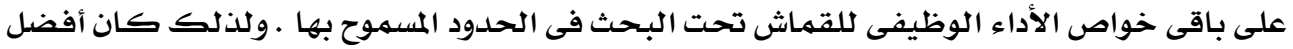

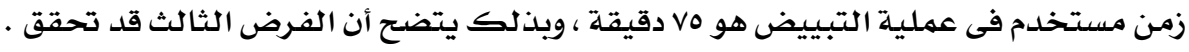
وبذلك نجد أن أنسب ظروف لتشغيل مادة بيربورات الصوديوم كالتالى : تركيز : V جم/ لتر ، درجة حرارة : 90 درجة مئويـة ، زمن : V0 دقيقة .

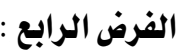

توجـد فـروق ذات دلادـة إحسصائية بـين نـوع مـادة التبيـيض المستخلدمة و كفــاءة الـصباغة للقماش تحت البحث • نتائج عمق اللون و خواص الثبات لعينات القماش تحت البحث : أولا : عمق اللون

جدول ( اء) اختبار ( T ) لدراسـة معنوية تأثير نوع مادة التبييض المستخدمـة على عمق اللون

\begin{tabular}{|c|c|c|c|c|c|c|}
\hline الدلالة & \begin{tabular}{|l} 
قيمة \\
(ت) \\
\end{tabular} & الحرجة & | العينة | & الالنحراف & |الحتوسط & ع/S عمق اللوز \\
\hline دال عند 0.01 & 4.68 & \multirow{2}{*}{5} & \multirow{2}{*}{6} & 0.316 & 4.900 & |العينات المبيضة بفوق أكسيد الهيدروجين| \\
\hline لصالح العينات المبيضة ببيربورات الصوديوم & 0 & & & 0.012 & 5.480 & العينات المبيضة ببيربورات الصوديوم \\
\hline
\end{tabular}

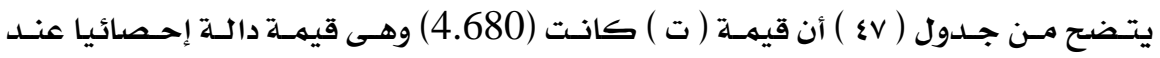

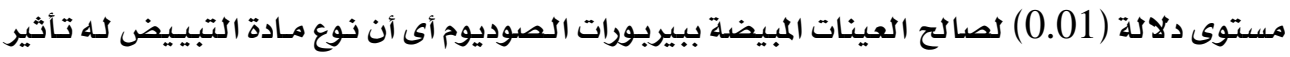

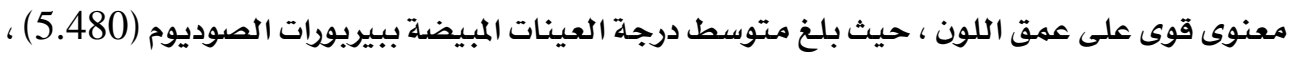

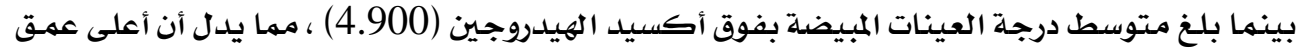

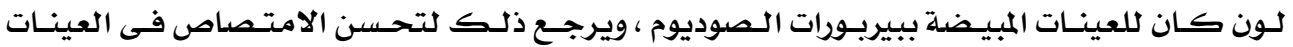

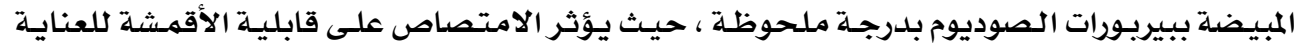

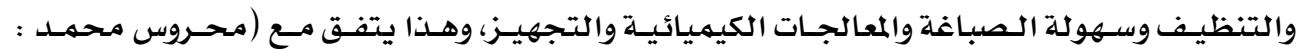
. ( r . q

ثانيا : خواص ثبات اللون ا- الثبات للغسيل

جدول (يء) اختبار ( T ) لدراسـة معنوية تأثير نوع مادة التبييض المستخدمة على الثبات للغسيل

\begin{tabular}{|c|c|c|c|c|c|c|}
\hline 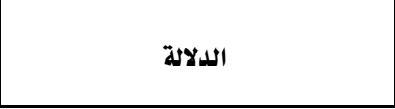 & قيمة & - د العرجية & العينة العية & |الانحراف & المتوسط & الثبات للفسيل \\
\hline \multirow{2}{*}{ 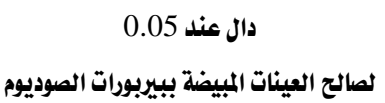 } & \multirow{2}{*}{2.613} & \multirow{2}{*}{5} & \multirow{2}{*}{6} & 0.427 & 3.333 & العينات المبيضة بفوق أكسيد الهيدروجين \\
\hline & & & & 0.303 & 4.000 & العينات المبيضة ببيربورات الصوديوم \\
\hline
\end{tabular}




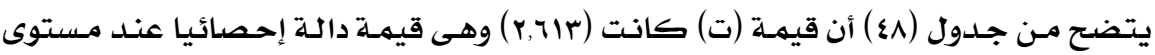

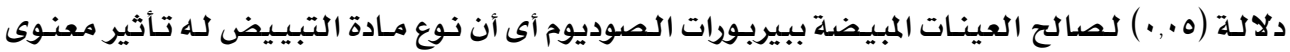

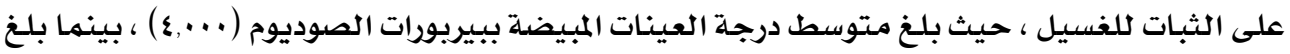

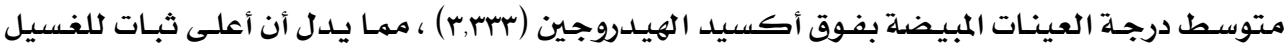

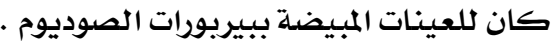

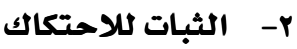
أولا : الثبات للاحتكاك الجاف :

جدول ( وء ) اختبار ( T ) لدراسة معنوية تأثير نوع مادة التبييض المستخدمة على الثبات للاحتكاك ( الجاف )

\begin{tabular}{|c|c|c|c|c|c|c|}
\hline الدلالة & قيمة (ت) & درجات العرية & العينة & الانعراف المعياري & المتوسط الحسابي & جاف \\
\hline \multirow{2}{*}{ | 0.175 غير دال| } & \multirow{2}{*}{1.581} & \multirow{2}{*}{ 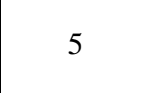 } & \multirow{2}{*}{6} & 0.516 & 4.333 & العينات المبيضة بفوق أكسيد الهيدروجين \\
\hline & & & & 0.473 & 4.400 & العينات المبيضة ببيرببورات الصوديوم \\
\hline
\end{tabular}

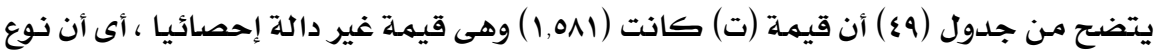

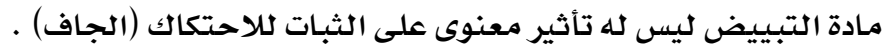

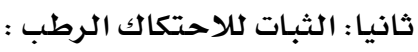

جلدول ( .0 ) اختبـار ( T ) لدراسـة معنوية تأثير نوع مادة التبييض المستخدمة على الثبات للاحتكاك ( الرطب )

\begin{tabular}{|c|c|c|c|c|c|c|}
\hline الدلالة & قيمة (ت) & 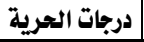 & 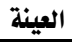 & الانحراف المعياري & | المتوسط الحسابي & رطب - ت إب \\
\hline \multirow{2}{*}{0.982 غير دال } & \multirow{2}{*}{0.223} & \multirow{2}{*}{5} & \multirow{2}{*}{6} & 0.715 & 4.000 & العينات المبيضة بفوق أكسيد الهيدروجين \\
\hline & & & & 0.362 & 3.996 & العينات المبيضة ببيربورات الصوديوم \\
\hline
\end{tabular}

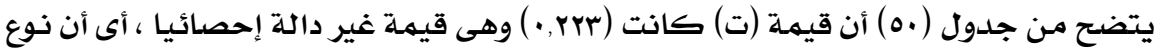

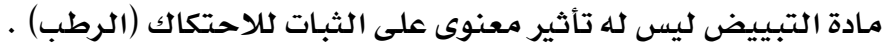
r- م- الثبات للعرق أولا : الثبات للعـرق الحامضى : جلدول ( اه ) اختبـار ( T ) لدراسـة معنوية تأثير نوع مادة التبييض المستخدمة على الثبات للعرق ( الحامضى )

\begin{tabular}{|c|c|c|c|c|c|c|}
\hline الدلالة & $\begin{array}{c}\text { قيمة } \\
\text { (ت) } \\
\end{array}$ & |درجات | الحرية & |العينة | & الانحراف & المتوسط & حامضي \\
\hline دال عند 0.05 & 2.77 & \multirow{2}{*}{5} & \multirow{2}{*}{6} & 0.196 & 3.433 & |العينات المبيضة بفوق أكسيد الهيدروجين \\
\hline لصالج العينات المبيضة ببيربورات الصوديوم & 2 & & & 0.360 & 4.000 & العينات المبيضة ببيربورات الصوديوم \\
\hline
\end{tabular}

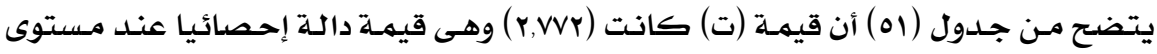

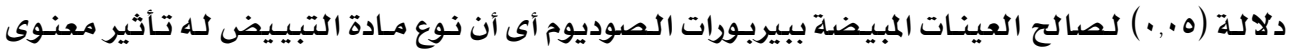


على الثبات للعرق (الحامضى)، حيث بلغ متوسط درجة العينات المبيضة ببيربورات الصوديوم ( ..., ؛)

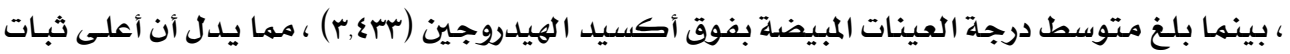

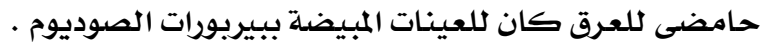
ثانيا : الثبات للعرق القلوى :

جدول ( rه ) اختبار ( T ) لدراسة معنوية تأثير نوع مادة التبييض المستخدمة على الثبات للعرق ( القلوى )

\begin{tabular}{|c|c|c|c|c|c|c|}
\hline الللالة & |قيمة(ت) & درجات & 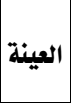 & الالنحياري & الحتوسط & 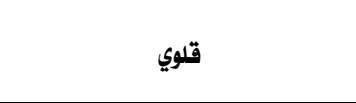 \\
\hline دال عند 0.01 & \multirow{2}{*}{5.246} & \multirow{2}{*}{5} & \multirow{2}{*}{6} & 0.753 & 3.000 & العينات المبيضة بفوق أكسيد الهيدروجين \\
\hline لصالح العينات المبيضة ببيربورات الصوديوم & & & & 0.313 & 4.000 & العينات المبيضة ببيربورات الصوديوم \\
\hline
\end{tabular}

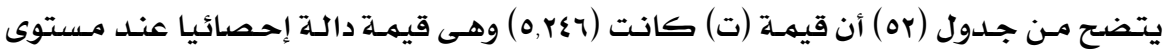

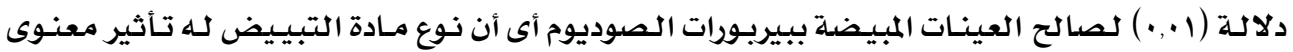

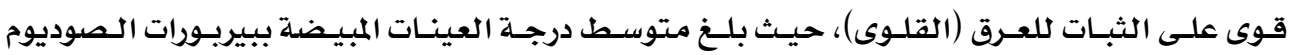

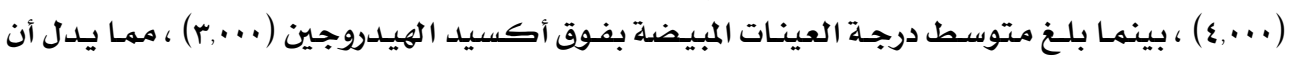

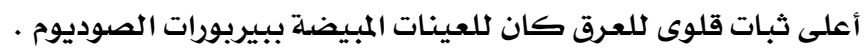
ع- الثبات للضوء

جدول ( به ) اختبار ( T ) لدراسـة معنوية تأثير نوع مادة التبييض المستخدمهة على الثبات للضوء

\begin{tabular}{|c|c|c|c|c|c|c|}
\hline 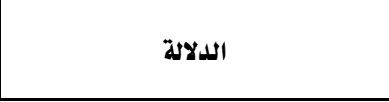 & قيمة & | درجات & | - العينة & الالمحراف & الحسابي & الثبات للضوs \\
\hline دال عند 0.05 & 2.9 & \multirow{2}{*}{5} & \multirow{2}{*}{6} & 0.382 & 6.366 & لعينات المبيضة بفوق أكسيد الهيدروجين \\
\hline لصالح العينات المبيضة ببيربورات الصوديوم & 18 & & & 0.419 & 7.000 & العينات المبيضة ببيربورات الصوديوم \\
\hline
\end{tabular}

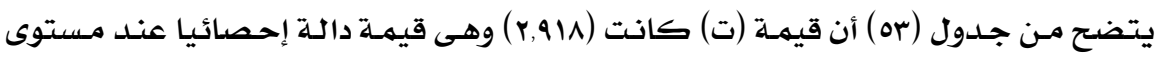

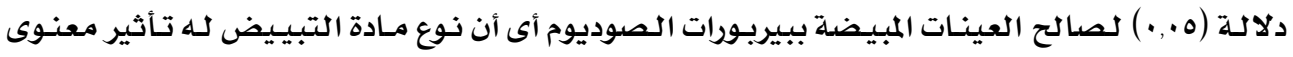

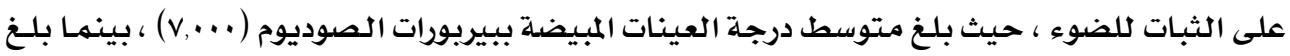

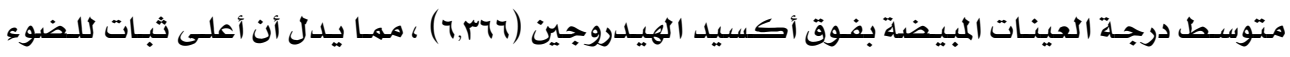

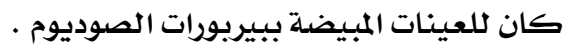




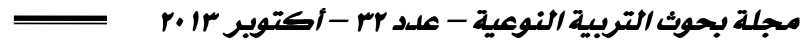

• تقييم الجودة لتأثير نوع مادة التبييض على خواص الأداء الوظيفى للقماش تحت البحث :

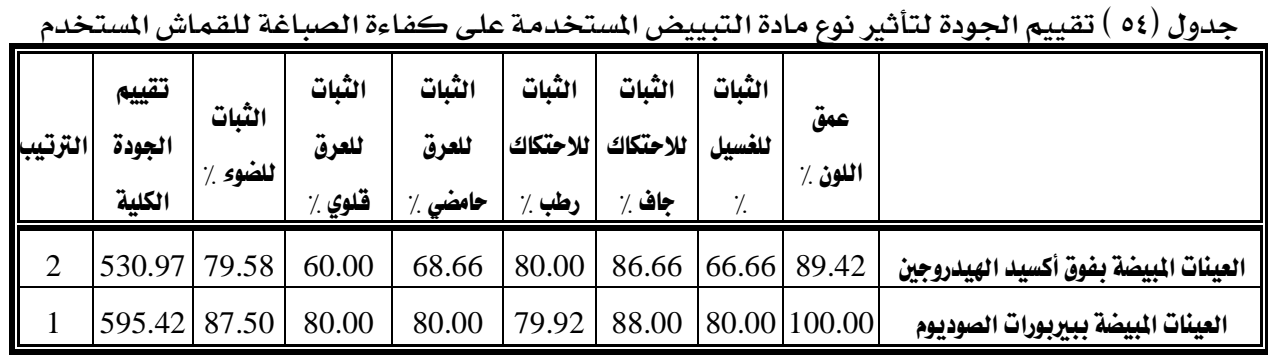

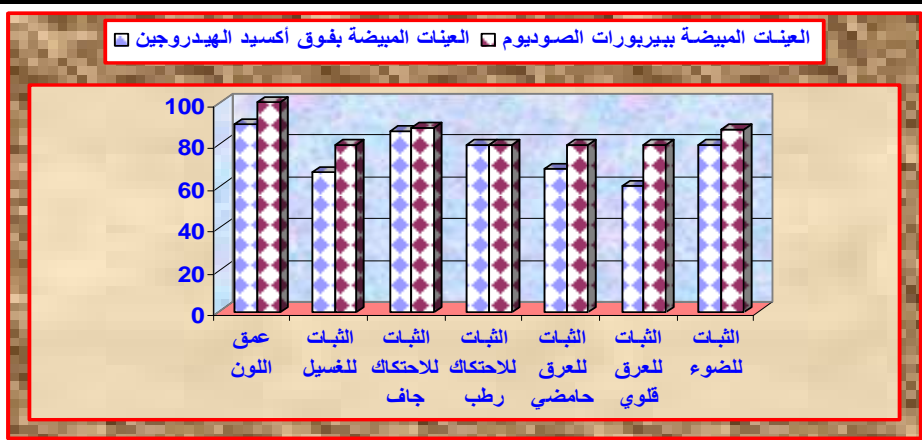

شكل( • ) تأثير نوع مادة التبييض المستخدمة على كفاءة الصباغة فى ضوء تقييم الجودة
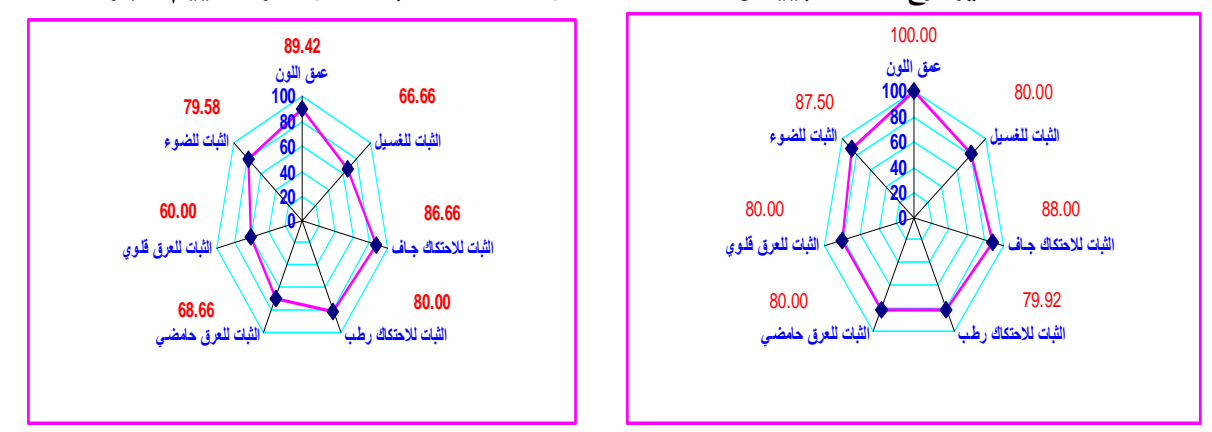

شكل (r ا ) أفضل العينات فى ضوء تقييم الجودة

شكل (11) أقل العينات فى ضوء تقييم الجودة

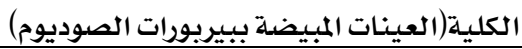

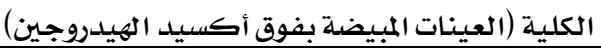

$$
\text { يتضح من جدول (عه) والأشكال (rا1/11) أن : }
$$

العينـات المبيـضة ببيربـورات الـصوديوم حققـت أعلـى تقيـيهم للجـودة الكليـة (595.42 ) ،

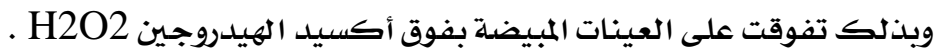

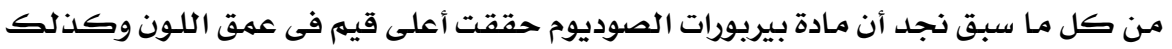

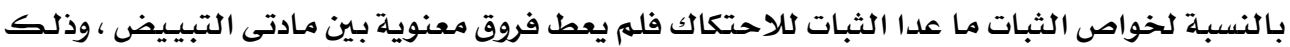


بالمقارنة بين مادتى بيربورات الصوديوم وفوق أكسيد الهيدروجين ، وبـلك يتضح أن الفرض الرابع

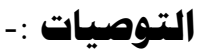

1- البحث عن مواد مؤكسدة أخرى يمكن استخدلامها كبـدائل لمادة فوق أكسيد الهيدروجين

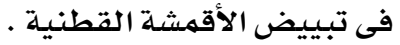

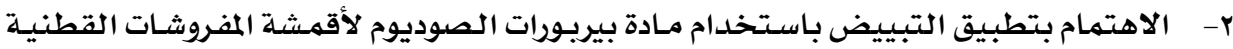

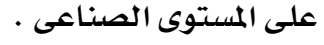

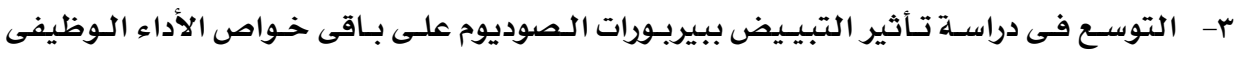

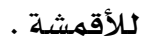

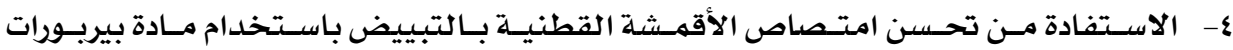

الصوديوم فى رفع كفاءة صباغة الأقمشة المبيضة بتلك المادة .

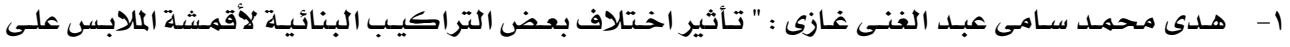

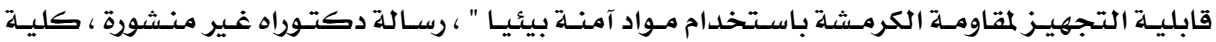

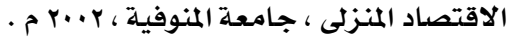

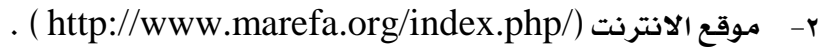

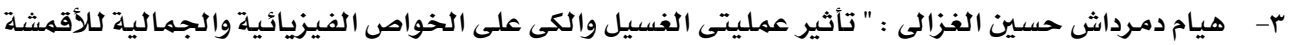

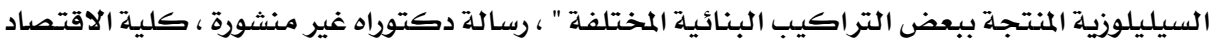

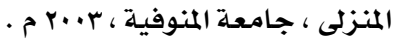

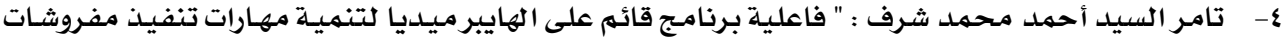

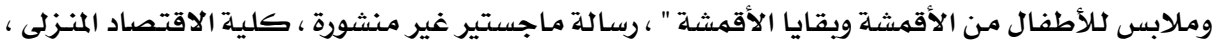

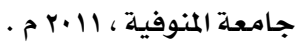

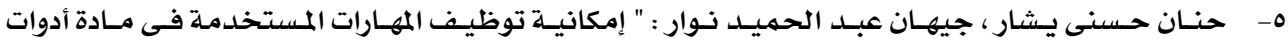

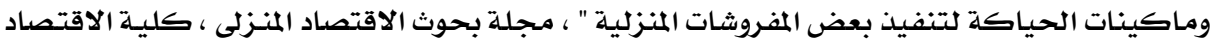

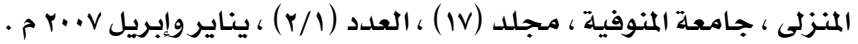

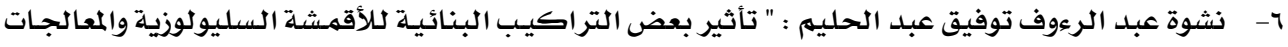

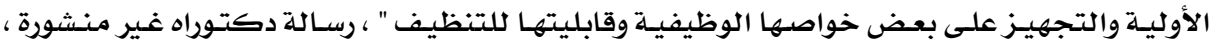

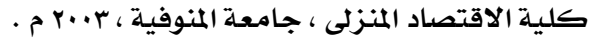

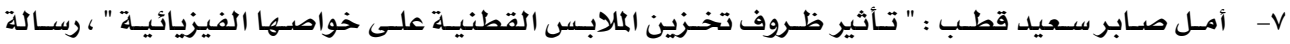

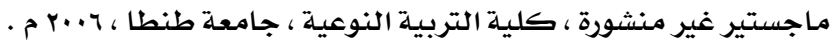

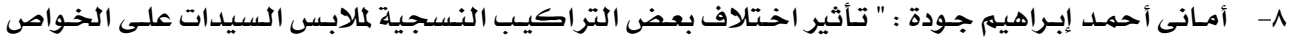

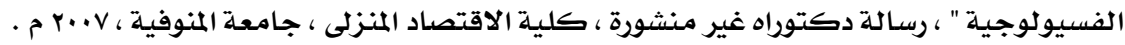




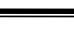

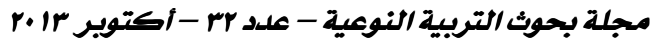

9- بيل عبد البـاسط إبـراهيه :" التحضيرات الأوليـة لكأليـاف السليلوزية ومخلوطاتها"، الاتجاهـات الحديثة فى تحضير وتجهيـز الأليـاف النسـيـية، الطبعـة الثانيـة ، أكاديهيـة البـحثث العلهـى والتكنولوجيـا ،وزارة

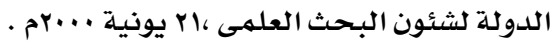

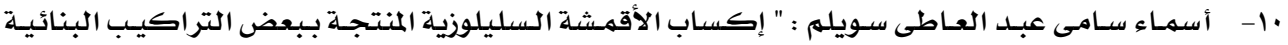
المختلفة والمستخدمهة فى الملابس الجاهزة خـواص العنايـة السهلة بطريقـة آمنسة بيئيـا " ، رسـالة دكتوراه

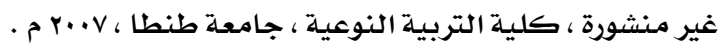

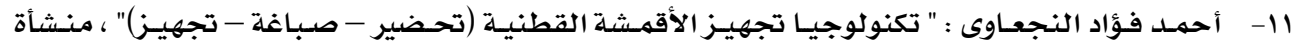

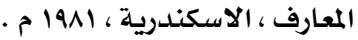

12- W.B.A.Chanal: "Desizing 2000- a combined desizing and demineralising process", Colourage, Vol. XLV111, No. 11, November 2000.

13- M.R.Sampath: "Frequently encountered problems in textile wet processing and diagnostic approach for preventationl solutions", Colourage, Vol. XLV111, No. 5, May 2001.

14- Mohamed M. Hashem: "Recent development bleaching of cotton based textiles",

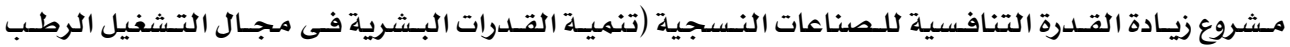
للمنسوجات) ، الجزء الأول ، غرفة الصناعات النسجية المصرية ، القاهرة ، ب... م م .

10- على على حبيث : " نحو وضـع خريطة تكنولوجية (Roadmap) للصناعة النسجية فى مـصر " ، مشروع

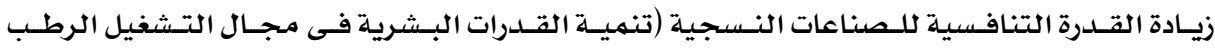
للمنسوجات) ، الجزء الأول ، غرفة الصناعات النسجية المصرية ، القاهرة ، ب... م م .

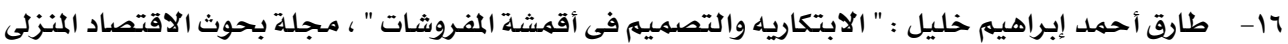

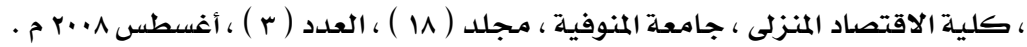

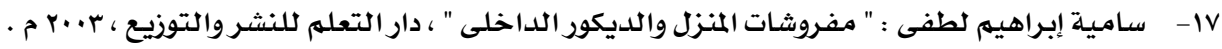

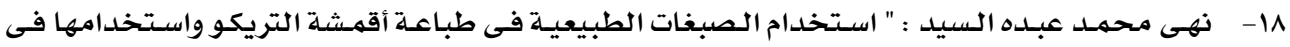

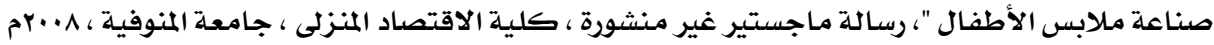
19- إلهام عبد العزيز محمد : " تأثير بعض المعالجـات الكيميائية والتراكيب البنائيـة على الخواص الوظيفية كلأقمسشة المستخحدمة لعـلاج " مـرضـى قـرح الفـراش " " ، رسـالة دكتـوراه غـير منسشورة ، كليـة الاقتصـاد

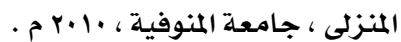
•r - - سمر أحمد مصبـاح قنونة : " تأثير بعض عوامل التركيب البنـائى النسجى لأقمسة البوليستر المصبوغة

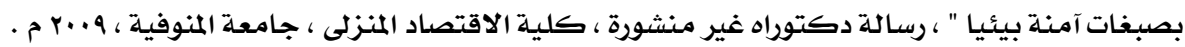

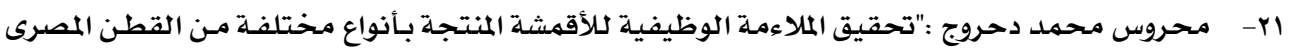
والمنفــة بـبعض التراكيـب البنائيسة لتنـاسـب ملابـس السـيدات" ، رسـالة دكتـوراه غـير منشـورة ، كليـة

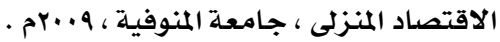


— تاثير التبييض باستخلامبيريورات الصوديوم على خواص الأداء الوظيفى لأقمشة المفروشات القطنية

\section{Effect Of Bleaching Using Sodium Perborate On The Functional Properties Of Cotton Upholstery Fabrics}

\section{Dr. Assmaa Samy Abd-ELaty Swelam*}

\section{ABSTRACT}

Cares search to find material bleaching oxidizing alternative to Hydrogen peroxide can be used in bleaching upholstery fabrics of cotton on the industrial level in the case of the existence of what hinders use of a Hydrogen peroxide such as high rate of Oxygen or prohibit the use, and determine the most appropriate (concentration, temperature, time to process bleach) that material, as the oxidizing bleach and chlorine-containing proven harmful impact on the environment and humans, so it was the study of the effect of bleach using Sodium perborate material on the physical and mechanical properties of the cloth under research and compare the impact of bleach with Hydrogen peroxide material. In order to identify the optimum conditions for the operation of Sodium perborate and arrive at the most appropriate bleaching material check best half-bleaching and the highest efficiency for dyeing cloth under the search. Therefore, the following variables were used:

- Concentration of Sodium perborate (3 g/ $1-5 \mathrm{~g} / 1-7 \mathrm{~g} / 1)$.

- The temperature of the bleaching process $\left(75^{\circ} \mathrm{C}-85^{\circ} \mathrm{C}-95^{\circ} \mathrm{C}\right)$.

- The time of the bleaching process $(45$ minutes - 75 minutes - 105 minutes).

The tests were conducted following: tensile strength, elongation ratio, the weight per square meter, the degree of whiteness, the absorption time of bleached samples either Sodium perborate or Hydrogen peroxide and comparison between them.

And after reaching the most appropriate conditions for the operation of Sodium perborate,the bleached samples with both the subjects of bleaching

* Lecturers: Clothes and Textiles, Home Economics Department, Faculty of Specific Education, Tanta University 
and the operating conditions their own were dyed with active dye and tests were conducted K/S, stability properties.

And then apply the appropriate statistical method on the results of these tests, and the most important findings of Search:

- The most appropriate conditions for the operation of Sodium perborate were: concentration of $7 \mathrm{~g} / 1$, temperature: $95^{\circ} \mathrm{C}$, time: 75 minutes.

These conditions achieve higher degree of whiteness of samples bleached by Hydrogen peroxide while maintaining physical and mechanical properties of the fabric used.

- Higher K/S for samples bleached by Sodium perborate so as to improve absorption in samples bleached by Sodium perborate compared samples bleached by Hydrogen peroxide significantly.

- Sodium perborate achieved the highest values in the color fastness properties except color fastness to rubbing is not given the significant differences between the two subjects of bleach, and that compared between the subjects Sodium perborate and Hydrogen peroxide. 